University of Montana

ScholarWorks at University of Montana

Graduate Student Theses, Dissertations, \&

Professional Papers

2010

\title{
Lead exposure in large carnivores in the greater Yellowstone ecosystem
}

Thomas Alan Rogers

The University of Montana

Follow this and additional works at: https://scholarworks.umt.edu/etd

Let us know how access to this document benefits you.

\section{Recommended Citation}

Rogers, Thomas Alan, "Lead exposure in large carnivores in the greater Yellowstone ecosystem" (2010). Graduate Student Theses, Dissertations, \& Professional Papers. 615.

https://scholarworks.umt.edu/etd/615

This Thesis is brought to you for free and open access by the Graduate School at ScholarWorks at University of Montana. It has been accepted for inclusion in Graduate Student Theses, Dissertations, \& Professional Papers by an authorized administrator of ScholarWorks at University of Montana. For more information, please contact

scholarworks@mso.umt.edu. 
LEAD EXPOSURE IN LARGE CARNIVORES IN THE GREATER YELLOWSTONE

ECOSYSTEM

By

THOMAS ALAN ROGERS

Bachelor of Arts, Colby College, Waterville, ME, 2004

Thesis

Presented in partial fulfillment of the requirements

for the degree of

Master of Science in Organismal Biology and Ecology

The University of Montana

Missoula, MT

May 2010

Approved by:

Perry Brown, Associate Provost for Graduate Education Graduate School

Dr. Kerry R. Foresman

Organismal Biology and Ecology \& Wildlife Biology

Dr. Daniel Pletscher

Wildlife Biology

Dr. Vanessa Ezenwa

Organismal Biology and Ecology \& Wildlife Biology 
Abstract: Exposure to heavy metals is a potential challenge to the conservation of wildlife. One source of heavy metal exposure known to negatively affect avian wildlife is ingestion of lead rifle bullet fragments found in discarded hunter-harvested ungulate gut piles. Some large mammalian carnivores, such as grizzly bears (Ursus arctos), are also known to target these gut piles as a food source while others, such as cougars (Puma concolor), avoid areas with high levels of human hunting pressure. I investigated whether large carnivores in the Greater Yellowstone Ecosystem were exposed to lead, and if so, if ammunition ingested from hunter-harvested gut piles was an apparent source of exposure. I tested samples of blood, tissue, and scat for the presence of lead in black bears (Ursus americanus), wolves (Canis lupus), coyotes (Canis latrans), grizzly bears and cougars. Grizzly bears show higher blood lead levels $(n=82$, median $=4.4 \mu \mathrm{g} / \mathrm{dL}$, range 1.1-18.6 $\mu \mathrm{g} / \mathrm{dL})$ than black bears $(n=44$, median=1.6, range $0.5-6.9 \mu \mathrm{g} / \mathrm{dL})$, but blood lead levels did not increase during the autumn hunting season when potentially lead-tainted gut piles are available. Wolves $(n=21)$ and cougars $(n=8)$ had lead concentrations near or below the minimum level of detection in both blood and tissue samples. No lead fragments were detected in the scat of grizzly bears, black bears, wolves, and coyotes in samples collected during the summer $(n=209)$ and fall $(n=214)$ in 2009. Therefore, unlike avian scavengers, mammalian scavengers do not appear to be ingesting lead ammunition fragments. Grizzly bears do, however, exhibit blood lead levels higher than what is considered safe in humans, but the source of this exposure remains unknown. 


\section{DEDICATION}

I dedicate this thesis to my sister, Jessica Rogers, for her guidance in my professional development; to Bryan Bedrosian for his collaboration and assistance and for giving me my first long-term field position; and to Julia Levine, for her patience and support through this process.

\section{ACKNOWLEDGEMENTS}

I would like to thank my advisor K. Foresman, and my graduate committee, V. Ezenwa, and D. Pletscher. I would like to thank my collaborators for this study, including S. Schmitz, C. Schwartz, M. Haroldson, M. Jimenez, M. Bruscino, M. Boyce, S. Cain, S. Wolff, S. Dewey, and their many field crews. Aid and assistance for this study was provided by researchers at Craighead Beringia South including B. Bedrosian, D. Craighead, H. Quigley, M. Parrish, S. Craighead, and field crews. Draft reviews, comments, advice, and assistance were provided by J. Rogers, D. Newton, T. Johnson, O.

Crino, J. Graham, R. Domenech, E. Greene, H. Langer, J. Berger, M. Krebs and J. Moore. Scat samples were analyzed in the office of Dr. M. Pruyn, DVM in Missoula, MT and Dr. E. Patterson DVM in Jackson, WY. I would also like to thank my field crew: A. Potticary, J. Boersma, J. Alberts, and S. Hilty. Funding for this research was provided by The Montana Chapter of the Wildlife Society, the Charles Redd Center for Western Studies, and the University of Montana, with donations-in-kind made by Craighead Beringia South. 


\section{TABLE OF CONTENTS}

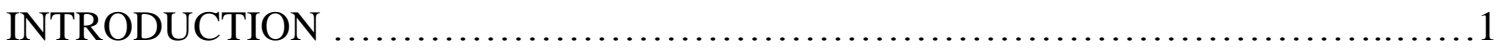

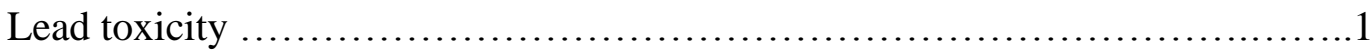

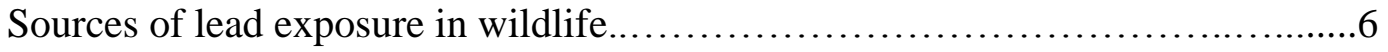

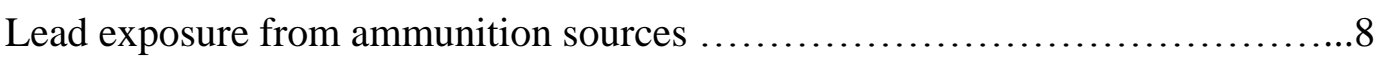

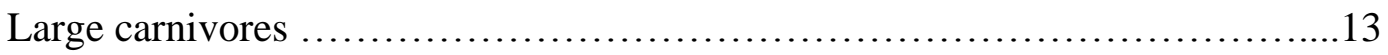

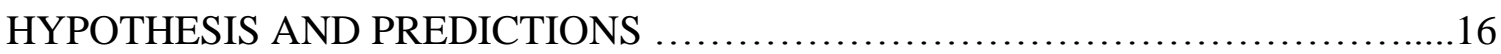

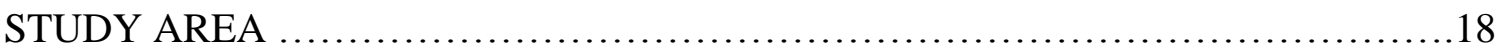

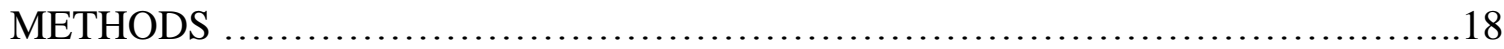

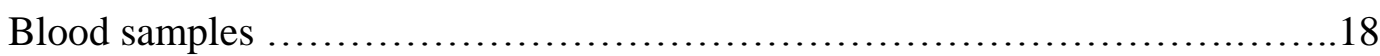

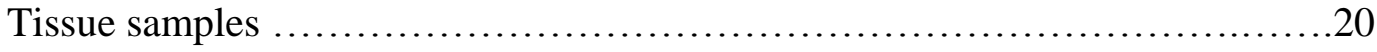

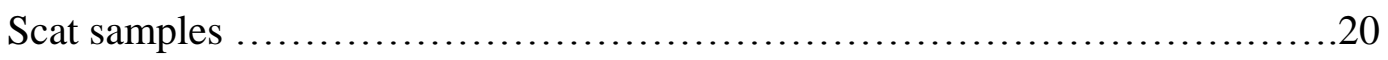

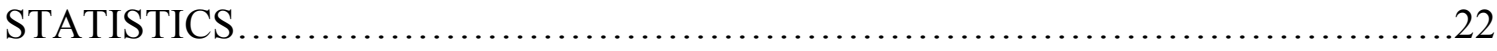

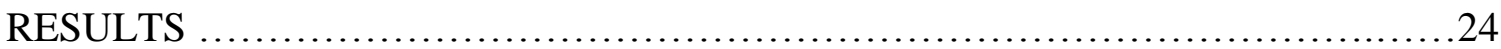

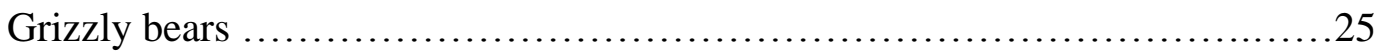

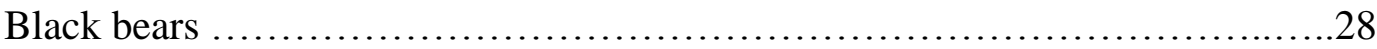

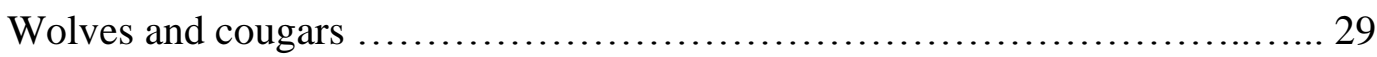

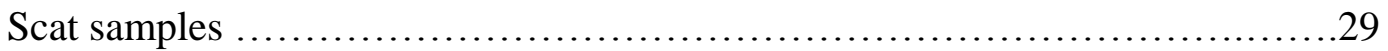

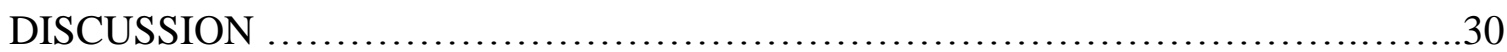

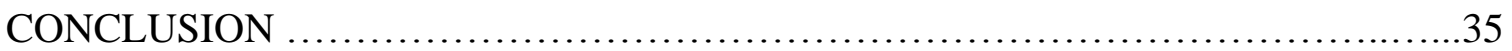

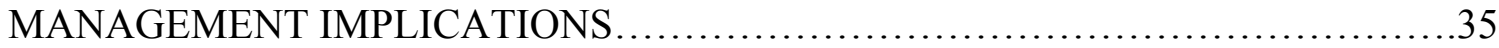

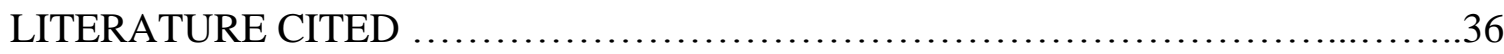

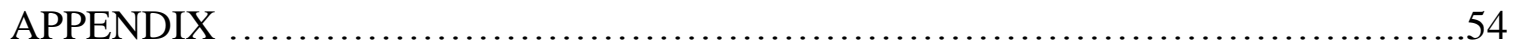




\section{LIST OF FIGURES}

Figure 1. Timescale of detection in scat, blood, tissue, and bone after lead exposure ......2

Figure 2. Grizzly bear blood lead levels throughout the year ........................23

Figure 3. Mean blood lead levels of grizzly bears, black bears, wolves, and cougars....24

Figure 4. Blood lead levels of grizzly bears, black bears, wolves, and cougars throughout

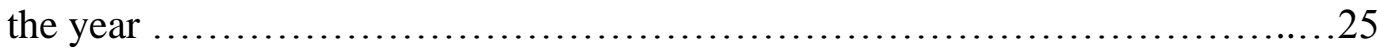

Figure 5. Map of capture locations of grizzly bears and their relative blood lead levels with the distribution of current and historical lead mines in the greater Yellowstone ecosystem.................................................27

Figure 6. Mean BLL of black bears and grizzly bears in Yellowstone National Park, Grand Teton National Park, and outside either park.........................28

Figure 7. Boxplot of the difference between values tested initially using the Leadcare ${ }^{\circledR}$ system and values measured during the retest...........................55

Figure 8. Scatterplot of the difference between the value measured during the initial test and the value measured during the retest using Leadcare ${ }^{\circledR}$ system..............56

Figure 9. Scatterplot of the difference between the value measured during the initial test and the value measured one year later during using Leadcare ${ }^{\circledR}$ system..........57 


\section{INTRODUCTION}

\section{Lead toxicity}

Lead has no known essential function in the cellular processes of higher vertebrates (White et al. 2007). On a cellular level, lead inhibits many of the same essential physiological processes in birds, humans, and other mammals (Todorovic et al. 2008), damaging the cognitive and neurological development of exposed individuals (Goyer 1993, Burger and Gochfeld 1997, Burger and Gochfeld 2000, Schnaas et al. 2006, Todorovic et al. 2008, Wu et al. 2008). Organisms suffer the greatest consequences of lead exposure during development (Gluckman and Hanson 2004, Wu et al. 2008).

After ingestion and absorption, lead is initially found in the bloodstream, causing blood lead levels (BLLs) to rise (Miranda et al. 2006, Navas-Acien et al. 2007). The exact rate of clearance of lead from the blood of an exposed individual varies among species and among exposure levels, but follows a generally predictable pattern (Fig.1). At lower levels of exposure $(2-5 \mu \mathrm{g} / \mathrm{dL}$ in blood), lead decreases below detectable levels in the blood within roughly a week (Hunt et al. 2009). After moderate to high levels of initial exposure (10-70 $\mu \mathrm{g} / \mathrm{dL}$ in blood), BLLs decline quickly over the first two weeks to one month (Miranda et al. 2006, Craighead and Bedrosian 2008). This is followed by a decrease in the rate of decline as lead deposited in bone and soft tissues begins to leach back into the bloodstream (Gwiazda et al. 2005, Miranda et al. 2006). As BLLs begin to decrease after initial exposure, lead begins to seep into soft tissues, particularly the liver and kidneys, and is present and detectable at elevated levels for 3-6 months after initial exposure (Dinius et al. 1973, Sharma et al. 1982, Todorovic et al. 2008). 


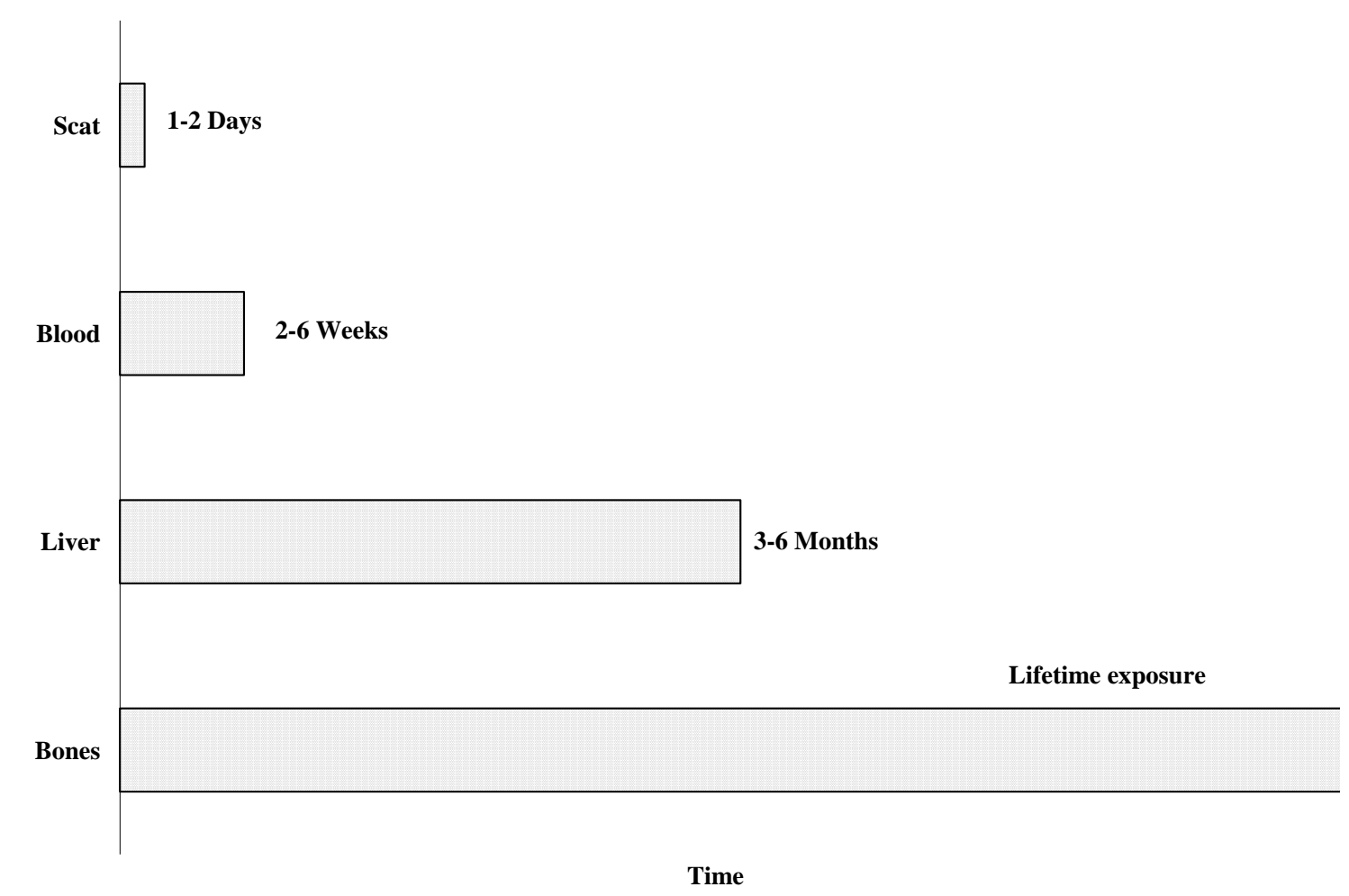

Figure 1. Time after initial exposure to lead in which lead is still detectable. Lead potentially present in scat samples is found in the form of particles visible on a radiograph. Lead potentially present in blood is detectable at the level of $\mu \mathrm{g} / \mathrm{dL}$ with the ESA Leadcare ${ }^{\circledR}$ testing system. Lead potentially present in bone and soft tissue is detectable at the level of $\mu \mathrm{g} / \mathrm{dL}$ with inductively coupled plasma mass spectroscopy. (Compiled from data from Dinius et al. 1973, Sharma et al. 1982, Gwiazda et al. 2005, Hunt et al. 2006, Miranda et al. 2006, Navas-Acien et al. 2007, Craighead and Bedrosian 2008, Todorovic et al. 2008, Hunt et al. 2009).

Lead mimics calcium by bonding with many of the same proteins that calcium bonds with, interfering with calcium-regulated cellular functions (Markovac and Goldstein 1988). When bonding to enzymes calcium normally bonds to, lead destroys the enzyme rather than bonding and moving on (Hacker et al. 1990). Bone is the primary storage site of calcium in the body and in the event of lead exposure, bone is also the primary site of long-term deposition of lead in the body (Barry 1981, Sharma et al. 1982, Hamilton and O'Flaherty 1995, Gangoso et al. 2009). Lead accumulates in bone more 
readily during youth, while bones are still growing, than during adulthood (Barry 1981). Lead found in bone frequently mobilizes back into the bloodstream, but this process happens slowly enough in humans that it does not typically cause BLLs to rise dramatically (Gwiazda et al. 2005).

Menke et al. (2006) suggested that no level of lead exposure is without a toxic effect and that BLLs as low as $2 \mu \mathrm{g} / \mathrm{dL}$ are associated with increased rates of mortality in humans. Higher BLLs are associated with increased blood pressure and risk of cardiovascular disease in adults (Navas-Acien et al. 2007). Adults with baseline BLLs in the range of $20-29 \mu \mathrm{g} / \mathrm{dL}$ have $39 \%$ increased mortality from circulatory problems and $68 \%$ increased mortality from cancer when compared with individuals whose baseline BLLs are $<10 \mu \mathrm{g} / \mathrm{dL}$ (Lustberg and Silbergeld 2002).

Children are particularly susceptible to negative consequences when exposed to lead (Goyer 1993). Dust from lead paint and consumption of lead paint chips are major contributors to lead exposure in children in the United States (Lanphear et al. 1998). Chronic lead exposure in children even at levels below $10 \mu \mathrm{g} / \mathrm{dL}$ is associated with deficits in hearing (Osman et al. 1999) and intelligence (Bellinger et al. 1991), even when exposure occurs during pre-natal stages of development (Schnaas et al. 2006). Lead may be passed to offspring through breast milk (Ettinger et al. 2004). Many adult neurological diseases and degenerative disorders arise as a result of fetal and infantile exposure to environmental toxins (Gluckman and Hanson 2004). Therefore, because lead most directly affects the developing nervous system for both pre- and post-natal offspring (Schnaas et al. 2006), lead exposure during youth has long-term negative consequences. 
Patterns of behavioral and physiological effects of lead exposure are relatively consistent across taxa. Lead is deposited in the tissues of lab rats following the same patterns as humans and many other birds and mammals tested, with higher affinity for lead among soft tissues in the liver and kidney, and long-term deposition in calcium rich areas such as bones and teeth (Smith et al. 2008, Todorovic et al. 2008). The level of lead deposition in these body parts is dose-dependent and is directly correlated with fecal output (Smith et al. 2008). Herring gulls (Larus argentatus) exposed to moderate levels of lead had difficulty with basic tasks of learning and sibling recognition, motor skills, and thermoregulation compared to control chicks (Burger 1998, Burger and Gotchfeld 2005). Gulls exposed to lead in the very first days after hatching exhibit many problems that are not seen in gulls exposed later in development (Burger and Gotchfeld 2000). This once again demonstrates the disproportionately strong negative effect that lead has on organisms exposed in the early stages of development. These studies on lab animals have given researchers a general understanding of the physiological mechanisms behind symptoms found in wild species affected with lead poisoning.

Because two of my study species are wild canids, it is important to note what effects lead may have by examining studies done on their domestic counterparts. Lead levels in dogs have been used as a method of determining the degree of lead contamination in urban and industrial areas (Koh and Babidge 1986, Ghisleni et al. 2004, Balagangatharathilagar et al. 2006). Like other mammals and birds, lead accumulates at greatest levels in the bone followed by the liver and kidneys of dogs (Hamir et al. 1981, Lopez-Alonso 2007). Domestic dogs that were experimentally fed high doses of lead compounds exhibited gastrointestinal problems, weight loss, and eventually death (Hamir 
et al. 1981). Low-level lead exposure in dogs, as in humans, is associated with hypertension (Fine et al. 1988), central nervous system lesions, and axonal degeneration (Hamir et al. 1984). Therefore, wolves (Canis lupus) and coyotes (Canis latrans) may likely demonstrate many of the same symptoms of lead exposure as domestic dogs if exposed.

While no researchers have published findings from experimentally feeding lead to bears to determine the physiological and behavioral effects of exposure, there have been two studies that investigated lead ingestion in wild grizzly bears (Ursus arctos) in central Europe. Like dogs and other mammals, grizzly bears have higher levels of lead in liver and kidney tissue than in muscle or heart tissue (Medvedev 1999, Celechovska et al. 2006). Grizzly bears exhibited lower levels of lead than large ungulates such as moose (Alces alces) and reindeer (Rangifer tarandus) and higher levels of lead than wild boar (Sus scrofa) or squirrels (Sciurus vulgaris) (Medvedev 1999). While both of these studies used different techniques to analyze lead levels and reported their findings in units that aren't directly comparable, neither of these studies concluded that lead concentrations found in grizzly bears in their respective study areas were of particular note (Medvedev 1999).

Several researchers have also documented heavy metal exposure in polar bears (Ursus maritimus, Rush et al. 2008). Lead levels in liver tissue of polar bears were lower than other heavy metals such as mercury (Norheim et al. 1992, Woshner et al. 2001, Rush et al. 2008). Lead levels in polar bears vary significantly throughout several study sites in the arctic, demonstrating that when different levels of lead exist in the environment, 
polar bear tissues reflect these differences in the degree of concentration of lead in their tissues (Kannan et al. 2007).

\section{Sources of lead exposure in wildlife}

Two of the current sources of lead exposure in wildlife are mining and industrial activity. The mines in northern Idaho's panhandle are a major source of lead exposure in wildlife (Henny et al. 1991, Sileo et al. 2001, Beyer et al. 2007). Waterfowl die-offs were occurring in the area throughout the early 1900s because waterfowl frequently ingest soil and sediment when foraging on the bottom of streams and ponds (Chupp and Dalke 1964, Blus et al. 1991, Blus et al. 1999). Lead levels in osprey (Pandion haliaetus) and fish downriver from the mining activity were significantly higher than birds and fish at control sites (Henny et al. 1991). Similarly, lead levels in hawks, falcons, and owls were higher downriver from the mines than at control sites (Henny et al. 1994). However, Henny et al. $(1991,1994)$ believed that lead levels in these raptors were not high enough to cause die-offs and may not have been biologically significant. This is likely because raptors are exposed less frequently to contaminated soil than waterfowl and fish which forage directly in river- and lake-bottom sediments (Henny et al. 1991, 1994). Lead remains relatively inert when deposited in soil and water, and plants do not readily take up lead deposited in soils and water within the normal range of acidity (Tsuji and Karagatzides1998, Holdner et al. 2004). Therefore, contaminated soil and mine tailings must be ingested directly for lead to have an effect, rather than ingested through plants or water sources (Beyer et al. 1997, Tsuji and Karagatzides 1998). Soil contaminated by mine tailings was the cause of death when examining the digesta or droppings of trumpeter swans (Cygnus buccinators, Blus et al. 1999), wood ducks (Aix 
sponsa, Beyer et al. 1997), and mule deer (Odocoileus hemionus) and white-tailed deer (Odocoileus virginianus, Beyer et al. 1997) in the Coeur d'Alene watershed, where lead contamination continues to be a wildlife conservation issue (Spears et al. 2007).

Other forms of lead exposure in wildlife include lead paint chips and industrial activity. Seabirds nesting on a decommissioned military base had lead paint chips in their nests and the geometric mean BLL of chicks in these nests was over 42 times higher than in control chicks (Finkelstein et al. 2003). In an area polluted with lead from industrial kiln dust, domestic goats had average BLL almost 9 times higher than the levels in goats from a non-polluted site (Oluokun et al. 2007). However, in fields contaminated with heavy metals from petroleum production, San Joaquin kit foxes (Vulpes macrotis mutica) did not show higher lead levels than control populations living in uncontaminated sites (Charlton et al. 2001). The difference between these two species may be that kit foxes ingest less soil than goats.

Leaded gasoline, once ubiquitous, began to be phased out in 1973 in the United States and continues to be phased out in countries around the world (Nriagu 1990). While in use, leaded gasoline caused BLLs in humans, wildlife, and domestic animals to rise, in addition to elevating lead levels in sediments throughout the nation and throughout the world (Nriagu 1990, Callender and Van Metre 1997). Lead levels in sediments in the United States follow closely the rise and fall of leaded gasoline, demonstrating that leaded gasoline was the major contributor to atmospheric and environmental lead in the twentieth century (Callender and Van Metre 1997). However, leaded gasoline has been virtually eliminated in the United States and Canada and is no 
longer a major source of lead contamination in humans or wildlife. Atmospheric lead levels have mirrored the decline of the use of leaded gasoline (Nriagu 1990).

Waterfowl may be exposed to lead upon ingesting lead sinkers and lead lures (Franson et al. 2003). Piscivorous birds such as common loons (Gavia immer) and brown pelicans (Pelecanus occidentalis) are the most common species found with lead fishing tackle in their stomachs (Locke et al. 1982, Franson et al. 2003). Ingestion of lead sinkers and lead shot accounted for $20 \%$ of mortality of trumpeter swans in the tri-state area of Montana, Idaho, and Wyoming (Blus et al. 1989). While lead sinkers may be present in large quantity in some aquatic ecosystems, there is no relationship between the density of lead fishing tackle and local water quality, again demonstrating that lead must be ingested directly through soil or through manmade artifacts to have a detrimental effect (Jacks et al. 2001).

\section{Lead exposure from ammunition sources}

The threat of lead poisoning from ingestion of shotgun pellets in upland game birds was first documented 137 years ago by British naturalist J. Hindle Calvert (1873). Calvert noticed pheasants were found with lead shot in their gizzards on pheasant preserves and were dying with paralyzed limbs. Since then, a variety of birds have also been shown to ingest shotgun pellets when foraging for grit to aid in mechanical digestion in their gizzards (Fisher et al. 2006).

Martinez-Haro et al. (2009) created a simulated gizzard and intestine of upland game birds with digestive acids and showed that lead shot dissolution varied depending on the types and concentrations of food and grit also in the digestive tract. Potts (2005) found that $4.5 \%$ of over 1,300 adult wild grey partridge (Perdix perdix) found dead on 
estates in the UK had lead shot pellets in their gizzard, and that $100 \%$ of birds found with 3 or more pellets in their gizzard died of lead poisoning. Other bird species that have shown to be at some risk of toxicity from lead poisoning include ruffed grouse (Bonasa umbellus), spruce grouse (Falcipennis canadensis), willow ptarmigan (Lagopus lagopus), and rock ptarmigan (Lagopus muta) (Rodrigue 2005).

One of the most well documented species of upland game birds affected by lead shot is the mourning dove (Zenaida macroura, Fisher et al. 2006). In one experiment, mourning doves that ingested even just one or two pellets showed an almost immediate spike in BLLs and also had higher lead levels in their liver and kidneys post-mortem (Schulz et al. 2007). In another experiment, mourning doves administered even a single lead pellet had rapid increases in BLLs within 24-hours, and death occurred in 104 out of 157 birds (Schulz et al. 2006). Ingestion of a single pellet by a mourning dove increased the rate of mortality by $24 \%$ (Buerger et al. 1986). In addition the chance of death increases by $18 \%$ for each pellet administered (Schulz et al. 2006).

The toxic effects of lead shot in waterfowl have been known almost as long as they have been recognized for upland game birds. The well-known naturalist George Bird Grinnell (1894) wrote a brief article about lead poisoned ducks he had observed over 100 years ago. Grinnell noted that the birds likely picked up the shot while foraging for aquatic vegetation on the bottom of ponds heavily hunted with lead shot, and that the shot was concentrated in the gizzard of the duck (Grinnell 1894).

Bellrose (1959) documented symptoms of lead poisoning in waterfowl by dissecting birds killed in lead pellet driven die-offs. Birds that had ingested lead pellets were found with food impaction and weakness and fatigue that prevented them from 
migrating (Bellrose 1959). He estimated that 4 percent of mallards in the Mississippi flyway in the 1950s died of lead poisoning. Bellrose (1959) noted that birds that ingested lead shot either passed it or died within 4 weeks, and birds weakened by lead were more likely to be taken by hunters. After the effects of lead became more widely known over the next several decades since Bellrose's (1959) publication, calls for restrictions against the use of lead shot increased. Restrictions on lead shot for waterfowl were implemented in the late 1970s in the US, starting with some Federal lands and increasing as more states began to implement their own bans (Scheuhammer and Norris 1996). However, there still are residual effects of hunting with lead shot that took place before bans went into effect. Lead pellet concentrations on heavily hunted wetland bottoms are still as dense as 148 pellets per $\mathrm{m}^{2}$ in some areas (Mateo et al. 2007a). Lead pellets remain near the surface of wetland bottoms $(<10 \mathrm{~cm})$ and may be available for consumption by waterfowl for 25 years or more (Flint and Schambler 2010). Therefore, while lead shot is no longer widely used for hunting waterfowl, the effects of its use are still seen today.

Lead core and solid lead bullets are widely used among hunters for large game mammals. They fragment substantially upon impact, spreading far beyond the site of impact (Hunt et al. 2006). Radiographs confirm that many of these fragments, which range in size from dust-sized fragments to several millimeters in diameter, remain in the gut pile (offal) left behind after the hunt (Hunt et al. 2006, Craighead and Bedrosian 2008). In addition, up to $21 \%$ of big game animals shot are killed but not recovered by hunters (Smith and Anderson 1998). These carcasses contain particles of lead throughout their body cavity (Hunt et al. 2006) and provide scavenging opportunities. Carcasses of animals shot with lead rifle bullets have been digested in the laboratory to confirm that 
particles apparent on radiographs are indeed pieces of lead in both prairie dogs (Cynomys spp., Pauli and Buskirk 2007) and Richardson's ground squirrels (Spermophilus richardsonii, Knopper et al. 2006).

In 1982, 11 of the 19 remaining wild California condors (Gymnogyps californianus) died and lead poisoning was attributed to the death of 3 out of the 4 recovered bird carcasses (Jannsen et al. 1986). California condors scavenging in areas of high hunting pressure exhibit high BLLs (Wiemeyer et al. 1988, Wynne and Stringfield 2007). Church et al. (2006) found that lead isotope ratios in the blood of condors matched lead isotope ratios in ammunition. Cade (2007) analyzed radiographs of condors that died from lead poisoning and saw fragments of lead bullets in the digestive tract. Agencies responsible for condor restoration still capture individuals affected by lead ingestion to undergo chelation every year to try to mitigate the toxic effects of lead (Green et al. 2008).

In addition to California condors, other species of scavenging birds such as turkey vultures (Cathartes aura) have shown evidence of lead ammunition ingestion and lead poisoning (Martin et al. 2003, Martin et al. 2008). Egyptian vultures (Neophron percnopterus) that are exposed to lead over many subsequent hunting seasons exhibit heightened levels of lead in their bones as they age (Gangoso et al. 2009).

In areas of high recreational big game hunting pressure, elevated BLLs in raptors have been documented during the hunting season (Fisher et al. 2006), and lead ingestion from rifle bullet fragments has been shown to be a cause of direct mortality in many birds of prey (Clark and Sheuhammer 2003), particularly in bald eagles (Haliaeetus leucocephalus) and golden eagles (Aquila chrysaetos, Wayland and Bollinger 1999, 
Domenech and Langer 2009, Neumann 2009). BLLs in over 1,000 common ravens (Corvus corvax) examined over several years directly correlated with local levels of elk harvest. These ravens exhibited significantly higher BLLs during the fall hunting season than during other times of the year (Craighead and Bedrosian 2008).

Raptors may also ingest lead when consuming waterfowl or upland game birds wounded by lead shot (Scheuhammer et al. 1996, Clark and Scheuhammer 2003), or when preying upon birds that have ingested lead shot into their gizzards (Kendall et al. 1996). Of 79 eagles investigated through radiography at a raptor rehabilitation and research center in Iowa, 4 had lead shot in their stomachs and 5 had fragments of rifle bullets in their stomachs (Kay Neumann 2010, unpublished data).

Fragments from rifle bullets and pellets from shotgun shells may also contaminate meat intended for human consumption. Lead rifle bullets fragment well past the point of entry in a big-game mammal (Hunt et al. 2006). These fragments are found in both biggame and small game meat consumed by people (Johansen et al. 2001, Hunt et al. 2009, Tsuji et al. 2009). Deer meat that was harvested with lead rifle bullets, butchered professionally, and prepared for human consumption was fed to domestic pigs (Hunt et al. 2009). This meat was contaminated with lead rifle bullet fragments, and pigs fed this meat had significantly higher BLLs than control pigs, demonstrating that pigs absorb lead from ammunition fragments found in game meat harvested and prepared using the same methods used for human consumption (Hunt et al. 2009). Cooking meat contaminated with lead may increase the level of exposure of people that eat it (Mateo et al. 2007b)

First nations people in Ontario subsisting largely on hunted game meat show elevated lead levels compared to local non-first nation communities that do not subsist on 
game meat (Tsuji et al. 2008a, Tsuji et al. 2008b). Lead isotope ratios from blood samples of community members most closely resemble lead isotope ratios from ammunition sources and do not match lead isotope ratios in local lichens, which are frequently used as a measure of environmental contamination for a particular study site (Tsuji et al. 2008a, Tsuji et al. 2008b). Lead in the blood of community members as a result of consumption of game meat harvested with lead bullets may be a public health issue for these communities (Tsuji et al. 2008c).

In summary, while the potential for direct mortality from lead poisoning is a clear threat to some species, the sub-lethal effects of lead ingestion is also a concern because lead suppresses the nervous and reproductive systems, which has been well documented in humans, laboratory animals, and wildlife (Goyer 1993, Burger and Gochfeld 1997, Burger and Gochfeld 2000, Menke et al. 2006, Wu et al. 2008).

\section{Large carnivores}

Samples for this study were collected from five target species (cougars (Puma concolor), coyotes, wolves, black bears (Ursus americanus), and grizzly bears) from the Northern Rocky Mountain and the GYE populations. These populations of coyotes, cougars, and black bears are not listed under the Endangered Species Act (USFWS 2010) and are considered "species of least concern" worldwide by International Union for the Conservation of Nature (IUCN 2010). However, the GYE grizzly bear population and the Northern Rocky Mountain wolf population are both considered Distinct Population Segments (DPSs), and have each gone through a series of delisting and re-listing over the

past several years (Rosen 2007, Bergstrom et al. 2009, USFWS 2010). Wildlife managers are undertaking massive recovery efforts to achieve sustainable populations of 
wolves and grizzly bears in the lower 48 states (Laliberte and Ripple 2004, Schwartz et al. 2006, Kasworm et al. 2007). The public has invested a tremendous amount of time and money in the return of wolves to the GYE and in management of threatened grizzly bear populations. Therefore it is imperative that researchers determine any ways in which anthropogenic changes to the environment may be negatively affecting the longterm survival and fitness of these animals.

Like avian scavengers, mammalian scavengers are also known to consume offal piles from hunter-harvested big game animals (gut piles, Wilmers et al. 2003a, 2003b). While nearly all vertebrate predators scavenge to some extent (DeVault et al. 2003), black bears, grizzly bears, wolves, cougars, and coyotes scavenge to highly varying degrees on gut piles and wounded animals (Ruth et al. 2003, Wilmers et al. 2003b, Haroldson et al. 2004).

Grizzly bears are frequent scavengers (Green et al. 1997), and are best known among mammalian predators to take advantage of gut piles and wounded elk as a food source, changing their movement patterns from areas protected within the boundaries of Yellowstone National Park (YNP) to areas of high hunting pressure during the fall hunting season (Ruth et al. 2003). Grizzly bears are also more likely to be in areas of high hunting pressure when alternative food sources such as whitebark pine (Pinus albicaulis) are less abundant (Haroldson et al. 2004). They are voracious eaters when consuming flesh, ingesting an average of $0.8 \mathrm{~kg}$ of food per minute (Wilmers et al. 2003b). Grizzly bear mothers with cubs, however, may avoid areas with nutrient rich food sources because of the threat of infanticide by adult male grizzly bears (Ben-David 
et al. 2004). Therefore, mothers with cubs may be less attracted than adult males to areas with concentrated food subsidies provided by hunters.

Black bears are known to scavenge when presented with the opportunity (Carson et al. 2000), although not to the degree of grizzly bears (Wilmers et al. 2003a). In the presence of dense grizzly bear populations, black bears may avoid highly desirable food resources to avoid conflicts with grizzly bears, particularly during years when those food resources are more limited (Belant et al. 2006). Therefore, while black bears may consume food supplements from hunters, they may not do so to the degree that grizzly bears seek out hunter-provided food supplements, and may avoid these supplements in the presence of grizzly bears.

Wolves also scavenge, but they do so to a much lesser extent than grizzly bears (Wilmers et al. 2003a, 2003b). In Alaska, wolves and grizzly bears each scavenged at over $50 \%$ of experimentally placed mammal carcasses and they consumed all available meat of large ungulate carcasses within 2-6 days of finding a carcass (Magoun 1976). However, during the fall elk hunting season in the GYE, some wolves and wolf packs leave the YNP boundaries possibly to scavenge on gut piles while others follow the movement of elk into the park and away from hunters (Ruth et al. 2003). Therefore, while wolves may take advantage of gut piles and wounded animals, they likely do so to a much lesser degree than grizzly bears (Ruth et al. 2003, Haroldson et al. 2004).

Coyotes are well-known scavengers (Wilmers et al. 2003a, 2003b, Jennelle et al. 2009), and are typically the dominant scavenger at a variety of food sources from bovine fetuses (Cook et al. 2004) to wolf kills (Wilmers et al. 2003a). Conversely, cougars avoid hunters completely and follow the movement of elk herds into the protective park 
boundaries of YNP (Ruth et al. 2003). Researchers consider scavenging a rare occurrence among cougars (Ackerman et al. 1984, Anderson and Lindzey 2003).

Few researchers have looked at heavy metals in large carnivores using blood or tissue samples (Dip et al. 2001, Millan et al. 2008) because of the inherent difficulty in sample collection. Two studies have investigated lead levels in large carnivores (Medvedev 1999, Celechovska et al. 2006), neither of which studied carnivores in North America, nor used blood samples. Furthermore, no researchers have investigated ammunition as a potential source for lead exposure in this important mammalian guild despite the potential opportunity for lead exposure in this group. Therefore, I investigated whether large carnivores in the GYE are being exposed to lead, and if so, if ammunition ingested from gut piles and unrecovered carcasses was an apparent source of exposure.

\section{HYPOTHESIS AND PREDICTIONS}

My goal of this research was to investigate two questions: 1) Are large carnivores being exposed to lead from their environment? and 2) Is lead from rifle bullet fragments a contributing source of lead exposure in large carnivores?

To test if large carnivores are being exposed to lead from their environment, I did a simple quantitative analysis of blood and liver tissue samples. I hypothesized that carnivores are being exposed to lead at detectable levels. I further hypothesized that lead ammunition is one contributing source of lead exposure in carnivores. If carnivores are being exposed to lead from lead ammunition from hunter-harvest ungulate gut piles, I predicted the following: 
1. Blood and liver tissue lead levels should be highest among grizzly bears, moderate to low among wolves, and lowest among cougars, based on known differences in responses to recreational big-game hunting for scavenging opportunities. Black bears should have lower BLLs than grizzly bears because they may avoid gut piles in the presence of grizzly bears to avoid conflict.

2. BLLs should be higher during the fall elk hunting season than during other times of the year, similar to other bird species such as common ravens.

3. Lead fragments should be present in scat piles after the individual has consumed lead rifle bullet fragments and it has passed through the gastrointestinal tract partially undigested.

4. BLLs should be higher for grizzly bears during years with lower alternative food resources such as whitebark pine seeds because grizzly bears are more likely to be in areas with high hunting pressure during these years.

5. BLLs may be higher during years in which grizzly bears have a higher number of aggressive encounters with humans, particularly with hunters. BLLs may also be higher for individuals who are considered problem bears that are more habituated and aggressive towards people and may therefore be more likely to take advantage of attractants such as scavenging opportunities from hunters.

6. BLLs may trend lower for grizzly bears captured within areas not open to hunting such as within the park borders of YNP. However, because grizzly bears may move vast distances in short periods of time, bears may be exposed to ammunition outside the park and then move into the park within a short time after exposure so there may be exceptions to this trend. 


\section{STUDY AREA}

I analyzed samples collected in Wyoming, Idaho, and Montana. The majority of samples collected came from the southern GYE in the Jackson Hole valley. The southern GYE includes 2 national parks (YNP and Grand Teton National Park, GTNP), the National Elk Refuge, and Bridger-Teton National Forest. This area provides an ideal setting for this study. It hosts a complete large carnivore guild including grizzly bears, black bears, wolves, cougars, and coyotes (Ruth et al. 2003). There is also one of the largest big-game hunts in North America resulting in abundant annual harvests (Wilmers et al. 2003b, Haroldson et al. 2004), in addition to roughly concurrent hunting seasons for moose, bison, and deer occur. Rifle hunting season for elk starts on or around 20 September in Wyoming; most of the blood and scat samples were collected in Wyoming. Rifle-hunting season for elk starts in mid-October in both Montana and Idaho. Elk hunting seasons end after most bears have gone into hibernation. These hunts provide an environment rich in food supplements in the form of hunter-wounded animals, skeletal frames with meat removed, and gut piles (Haroldson et al. 2004, Craighead and Bedrosian 2008).

\section{METHODS}

\section{Blood samples}

Blood lead level (BLL) is a standard indicator for acute exposure to lead (Goyer 1993, Menke et al. 2006). Blood samples were collected from free-roaming wild wolves, cougars, black bears, and grizzly bears by collaborating biologists from the Interagency Grizzly Bear Study Team, Grand Teton National Park, the U.S. Fish and Wildlife Service Interagency Wolf Recovery Team, the Teton Cougar Project, and Wyoming Game and 
Fish. Blood samples were taken from animals that were captured for research and management purposes independent of this study. Animals were handled according to Animal Care and Use protocols defined by those individual agencies and approved by the Institutional Animal Care and Use Committee at The University of Montana. Samples were collected at the time of capture and were stored refrigerated or frozen in $0.2 \%$ EDTA blood tubes. Individuals captured multiple times over the course of the study were considered independent samples if they were captured more than 3 months apart because any lead present in the blood at the time of initial capture would no longer be in the bloodstream by the time of recapture (Miranda et al. 2006, Craighead and Bedrosian 2008).

Blood samples were analyzed using the ESA Leadcare ${ }^{\circledR}$ System (LCS, Craighead and Bedrosian 2008), which gives results in units of $\mu \mathrm{g} / \mathrm{dL}$. In some species, LCS may give results that are slightly lower than other methods of lead analysis such as inductively coupled plasma mass spectrometry (ICPMS) but is still useful to compare the level of exposure of individuals (Bedrosian et al. 2009). The analyzer was calibrated using bovine blood controls provided by ESA before each set of tests and the readings were all within the expected range of values. In addition, a subset of grizzly bear samples were rerun one year after initial tests $(\mathrm{N}=8)$, several weeks after the initial test $(\mathrm{N}=6)$ and immediately after the initial test $(\mathrm{N}=1)$. Results trended slightly lower than the original test result for samples re-tested one year later, but the difference was not significant and the correlation was strong $\left(\mathrm{R}^{2}=0.96\right.$, see appendix). One outlier was recorded that was roughly $13 \mu \mathrm{g} / \mathrm{dL}$ lower than the original test result that was attributed to processing error. The lower limit of LCS, below which an individual reading is no longer 
considered accurate is $3.3 \mu \mathrm{g} / \mathrm{dL}$. All results below this number may therefore be considered simply "below $3.3 \mu \mathrm{g} / \mathrm{dL}$." For this analysis, the value given by the machine was used, because this value may be more accurate than reporting a result of either 3.3 or $0.0 \mu \mathrm{g} / \mathrm{dL}$.

\section{Tissue samples}

Liver samples were collected from individuals killed for management purposes independent of this study. Samples were analyzed using ICPMS at the Michigan State University Center for Population and Animal Health. While blood samples give a measure of exposure to lead within the past several weeks, lead levels in liver samples indicate level of exposure to lead within the past 3-6 months (Dinius et al. 1973, Sharma et al. 1982, Todorovic et al. 2008).

\section{Scat samples}

Scat samples were collected by walking trails in and around areas open to fall elk hunting in Grand Teton National Park and Bridger Teton National Forest. Each pile of scat was counted as one sample. If two piles were within a few meters of each other, they were designated as separate samples if they differed in apparent age or in contents.

In addition to samples collected in the field, bear scat from individuals captured for research and management purposes that was left behind in the trap was also included in the analysis. This allowed me to potentially match high or low lead levels in blood samples with the presence or absence of lead particles in scat samples for an individual.

The date and GPS location was recorded for each sample collected. Samples were designated with a subjective estimate of time since deposition on a scale from more recent (1) to less recent (3). The contents of each scat (meat, nuts, seeds, berries, 
vegetation, bone, hair, etc.) were recorded. Scat samples were collected during the months of June, July, and August for a summer subset, and during the month of October for an autumn subset.

Samples were identified to genus using visual field identification marks (Halfpenny 2001). Scat samples that were identified as canid and that were $\geq 30 \mathrm{~mm}$ in diameter were considered wolf samples and samples $<30 \mathrm{~mm}$ were considered unknown Canis spp. samples (Weaver 1979). I was unable to assign a species to samples identified as bear scat because there is not a defined method for distinguishing these samples with certainty in the absence of analyzing DNA (Kendall et al. 1992).

Each scat sample was autoclaved and dried in a drying oven. Samples were then ground with a coffee grinder and placed in a Petri dish on a labeled 14/17 inch cardboard grid. Petri dishes were radiographed at a local veterinarian's office and the radiographs were digitized. Small lead particles such as those coming from lead rifle bullet fragments or lead shot are visible by radiograph and are discernable from bone or other fragments (Hunt et al. 2006, Pauli and Buskirk 2007, Hunt et al. 2009). Two Petri dishes with ground carnivore scat were used as controls. In one dish, I experimentally placed discharged shotgun pellets and in the second I placed lead filings shaved off the discharged shotgun pellets. Lead and lead fragments from both controls were easily visible on the radiographs and served as a benchmark with which I was able to compare visible, bright white patches on the radiographs of sample Petri dishes.

Radiographs were digitally enhanced to increase contrast. Because the Petri dishes remained in the cardboard grid, the orientation was unchanged from the time radiographs were taken. Any scat samples containing bright white spots or blotches that 
looked like potential lead fragments were present were dissected and the particle was located. Dense shards of bone and gravel were disregarded.

Any particles that looked like potential fragments of lead ammunition were analyzed at the University of Montana Electron Microscopy Facility. Methods for electron microscopy were following the instructions from the Quartz Imaging Corp. Vancouver, BC, Canada as follows:

Dry organic samples were placed on a sticky carbon tab on a $12 \mathrm{~mm}$ aluminum SEM stub. The stubs were placed, uncoated, in a Hitachi S-4700 Scanning Electron Microscope and imaged at 10kv. EDX analysis was performed on selected regions of the samples at magnifications of $250 \mathrm{x}-450 \mathrm{x}$ with a scanning time of 90 seconds. Data was collected in graphic form and as tables indicating weight percent of elements observed in the samples.

\section{STATISTICS}

I performed a Shapiro-Wilk test to determine that the data were right skewed for both black bears $(W=0.84, P<0.01)$, and grizzly bears $(W=0.81, P<0.01)$ I did a $\log$ transformation which normalized the distribution for both black bears $(\mathrm{W}=0.98, P=$ $0.73)$ and grizzly bears $(W=0.98, P=0.18)$. I then performed all parametric tests to analyze the data. Because there was a general trend of increasing BLLs in grizzly bears sampled later in the year regardless of whether they were sampled before or during the hunting season $\left(R^{2}=0.026, P=0.04\right.$, Fig. 2$)$, I tested these data using a segmented regression model to determine if the slope changes from before hunting season to during hunting season. The segmented regression determined the slope before the hunting season started and after the hunting season started and compared the two to see if the onset of hunting season changes the slope of the line in any meaningful way. I also ran a segmented regression in both the populations inside and outside YNP to test for a 
difference in hunting and non-hunting season blood lead levels in both populations independently.

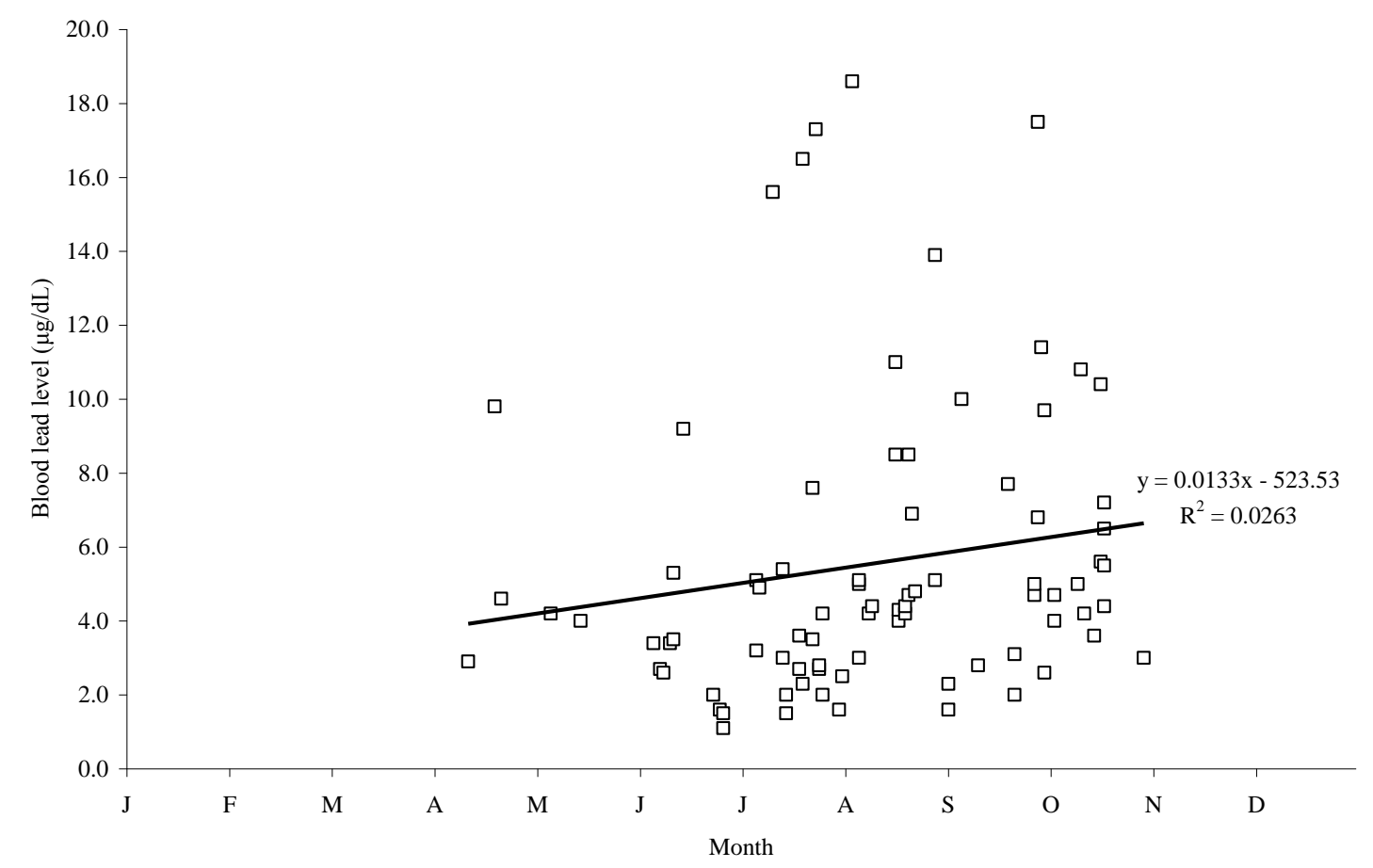

Figure 2. Blood lead level (BLL, $\mu \mathrm{g} / \mathrm{dL}$ ) for grizzly bears captured from 2007-2009. There was slight general trend $\left(R^{2}=0.0263\right)$ of increasing blood lead levels during the year $(P=0.04)$. Many of the highest BLLs recorded were taken from bears captured during July and August before the fall hunting season.

Comparisons to determine possible difference based on sex, reason for capture, or problem bears were performed using independent t-tests of BLL. To determine if age was correlated with BLL, I performed a simple linear regression of age versus BLL. To compare BLL of black bears and grizzly bears captured in YNP, GTNP, and outside either park, I performed an ANCOVA using a general linear model. Because blood samples collected outside either GTNP or YNP tended to have more days between collection and analysis for grizzly bears (Pearson correlation $0.46, P<0.01$ ) and black bears (Pearson correlation $0.38, P=0.03$ ), I included this as a random variable in the 
ANCOVA to control for this effect. Pair-wise comparisons were made using a Bonferroni post hoc test. To do a very basic spatial analysis to determine if bears captured in one part of the study area had different BLLs than those captured in another part, I performed a linear regression of BLLs against latitude and BLL against longitude. To compare BLL among the 4 test species, I performed a one-way ANOVA. No statistical tests were performed on liver tissue samples because there was not a large or complete enough sample size to make meaningful comparisons.

\section{RESULTS}

I tested blood samples from four carnivore species: grizzly bears $(n=82)$, black bears $(n=35)$, wolves $(n=12)$ and cougars $(n=6)$. In addition, I tested liver tissue samples from wolves $(n=9)$ and cougars $(n=2)$. BLLs in grizzly bears were significantly higher than all other species tested $(P<0.01$, Fig.3).

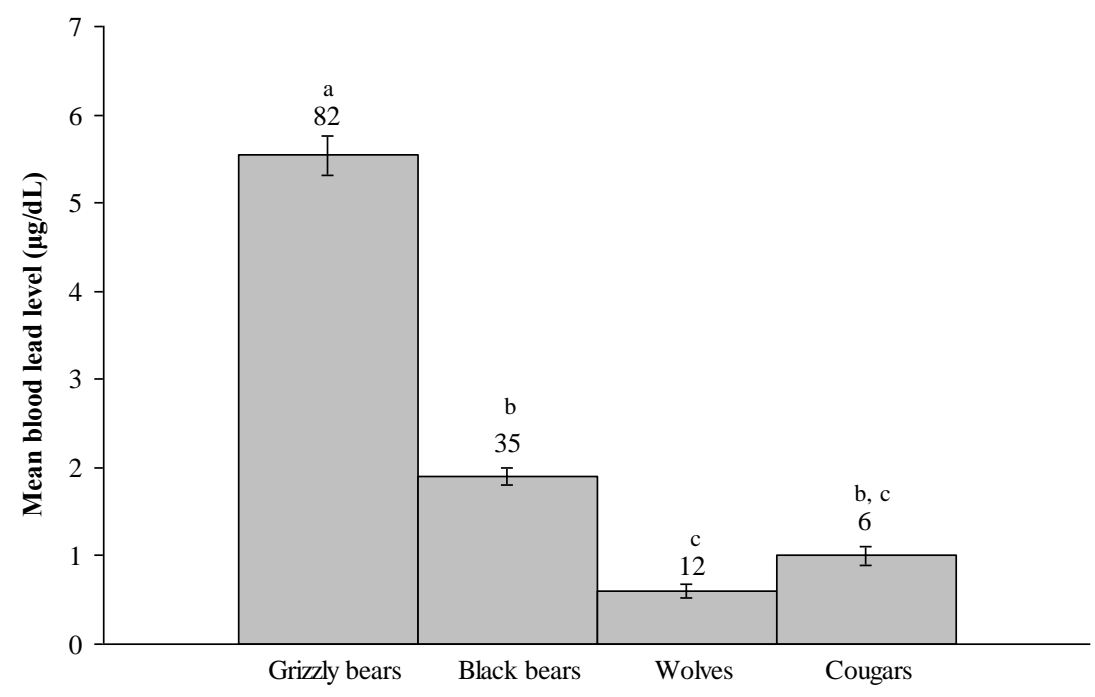

Figure 3. Mean blood lead level (BLL) in $\mu \mathrm{g} / \mathrm{dL}$ for grizzly bears, black bears, wolves and cougars, captured from 2007-2009 in the greater Yellowstone ecosystem with standard error bars and sample sizes. Species that are not statistically different $(P \leq 0.05)$ are labeled with the same letter above the sample size 
Black bears had lower BLLs than grizzly bears $(P<0.01)$ and higher BLLs than wolves $(P<0.01)$. I did not collect a large enough sample size of cougar blood samples to make a meaningful statistical comparison between cougar and black bear and between cougar and wolf BLLs.

\section{Grizzly bears}

I tested blood samples from 82 grizzly bears captured during $2007(n=15), 2008$ $(n=38)$, and $2009(n=29)$. There was no difference in BLLs in grizzly bears across the three years of the study, so data from the three years were pooled $(F=0.207, P=0.81)$. The median grizzly bear BLL was $4.4 \mu \mathrm{g} / \mathrm{dL}$ and results ranged from 1.1 to $18.6 \mu \mathrm{g} / \mathrm{dL}$. The highest BLL tested in grizzly bears was from a bear captured before the start of the hunting season, as were 7 out of the 11 bears with BLLs above $10 \mu \mathrm{g} / \mathrm{dL}$ (Fig. 4).

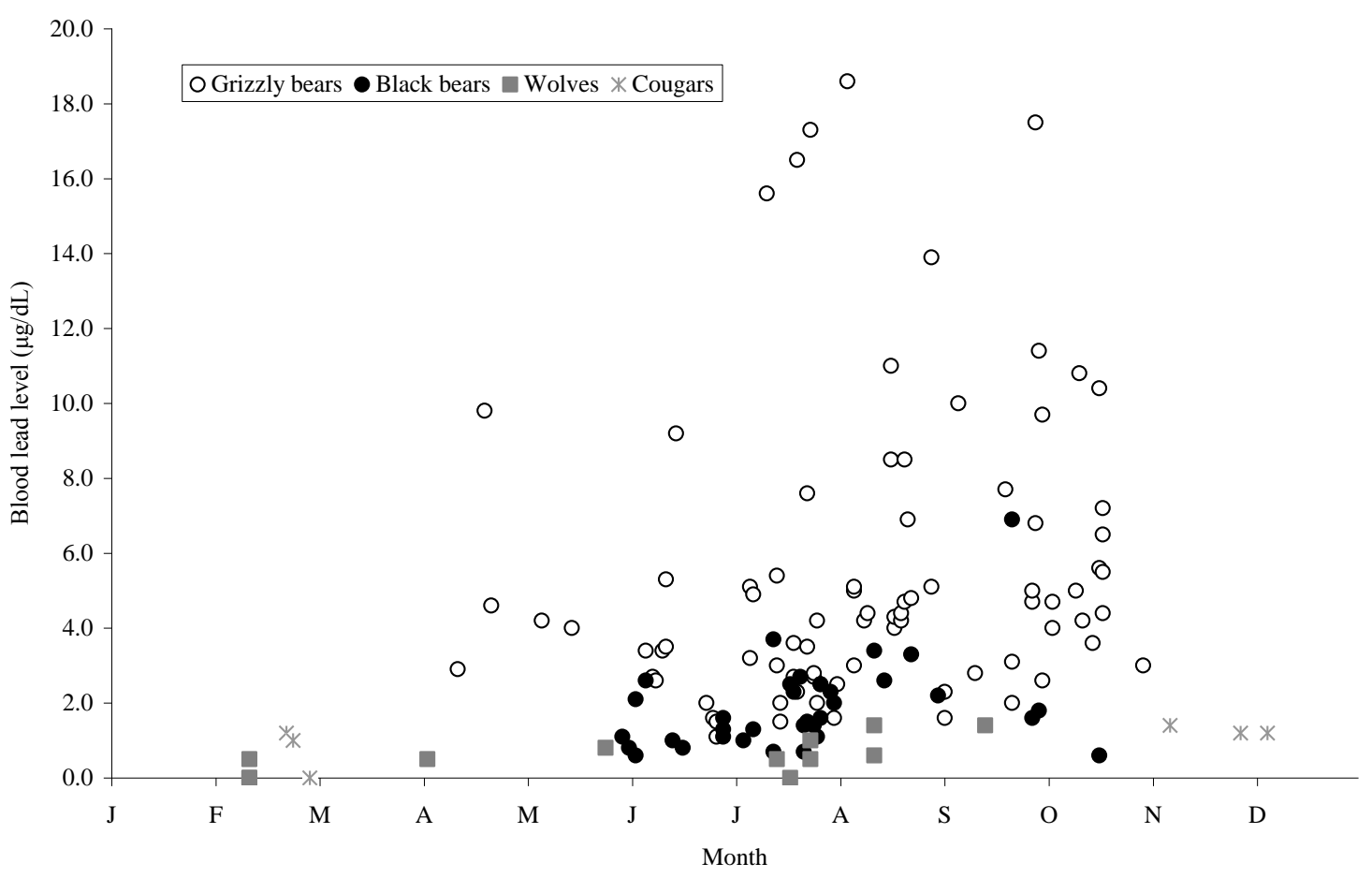

Figure 4. Blood lead level of grizzly bears $(n=82)$, black bears $(n=35)$, wolves $(n=12)$ and cougars $(n=$ 6) captured from 2007-2009 in the greater Yellowstone ecosystem. 
Grizzly bears captured after the Sept 20 start of hunting had higher mean BLLs than grizzly bears captured before this date $(\mathrm{z}=-2.137, P=0.02)$. However, in a segmented regression model, there was no difference in slope of BLLs in grizzly bears captured before $(n=59)$ and after the Sept 20 start of hunting season $(n=23)(\beta<0.001, P=$ 0.95). Therefore, after controlling for the trend of an increase in BLLs later in the year, BLLs before and during the hunting season in grizzly bears were similar. When the populations inside and outside YNP were analyzed separately there was still no difference between BLL before and after the Sept 20 start of hunting season $(\beta<0.01, P$ $=0.34$ inside YNP, $\beta<-0.01, P=0.73$ outside YNP).

I found no significant difference in BLLs in independent t-tests between male $(n=$ 54 ) and female grizzly bears $(n=28, t=1.26, P=0.21)$, nor between bears captured for research $(n=55)$ or management purposes $(n=27, t=0.04, P=0.97)$. I found no correlation between age and BLLs $(\mathrm{F}=0.123, P=0.77)$. Problem bears were defined as individuals removed or euthanized because they showed aggressive behavior towards people or property. I found no significant difference between problem bears $(n=24)$ and non-problem bears $(\mathrm{n}=58, t=0.03, P=0.74)$.

Grizzly bears did not trend higher BLLs in the North-South $(F=0.097, P=0.76)$ or the East-West $(F=0.915, P=0.34)$ directions. Similarly, there did not appear to be geographic clusters of higher or lower BLLs (Fig. 5). Bears captured outside YNP and GTNP had higher BLL than bears captured within YNP $(95 \%$ CI $(0.05,0.24), P<0.01$, Fig. 6). 


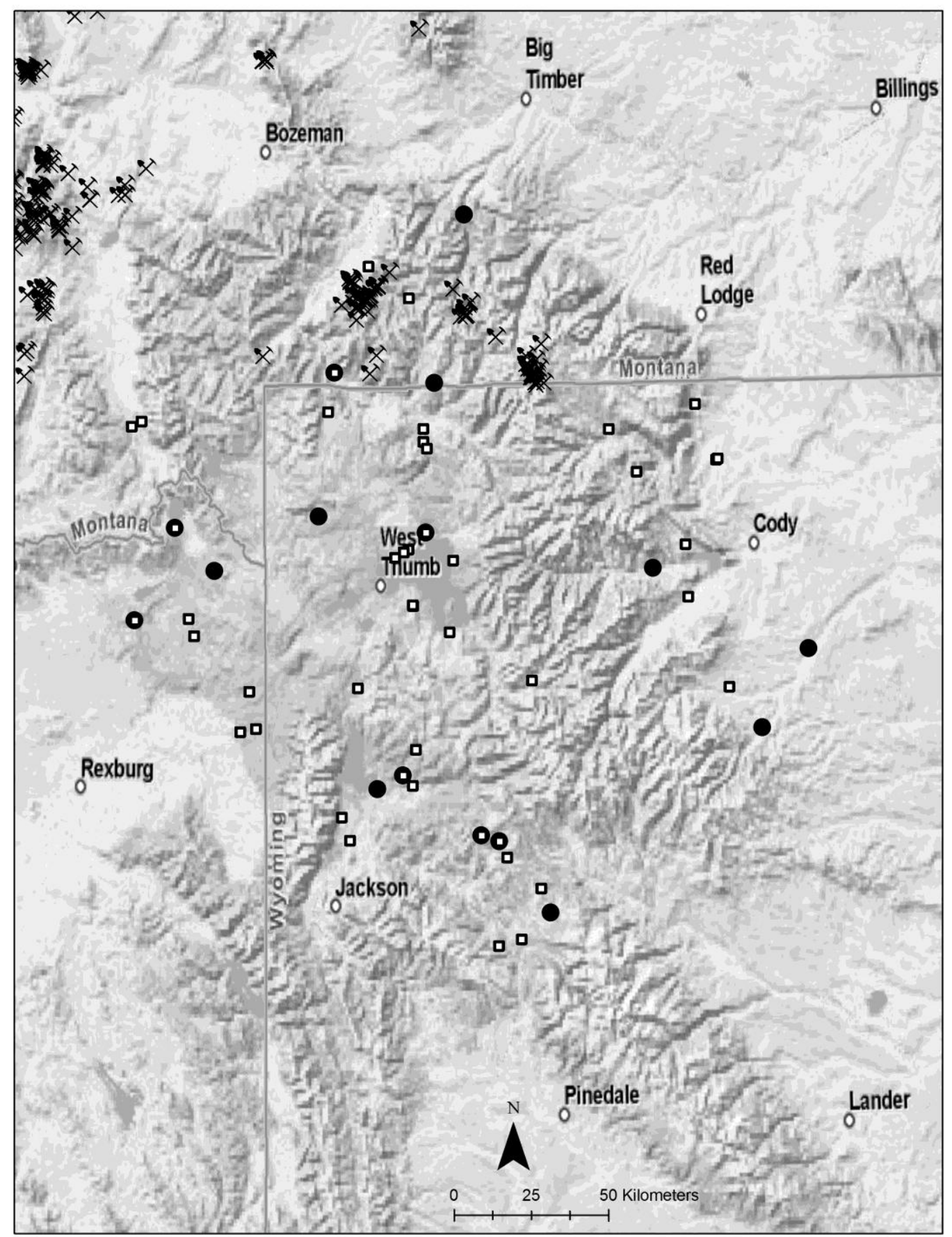

Figure 5. Distribution of grizzly bear captures from individuals tested for blood lead from 2007-2009 in the greater Yellowstone ecosystem. Individuals marked with a black circle had blood levels $\geq 8 \mu \mathrm{g} / \mathrm{dL}$; those marked with a white square were below this level. There does not appear to be any cluster of higher blood lead levels. The shovel and pickaxe symbols indicate locations of current and historical lead mines throughout the greater Yellowstone ecosystem. Lead mines are concentrated along the northern border of Yellowstone National Park and have no correlation with blood lead levels of grizzly bears (Data from United States Geological Survey, Washington, D.C., 2010). 


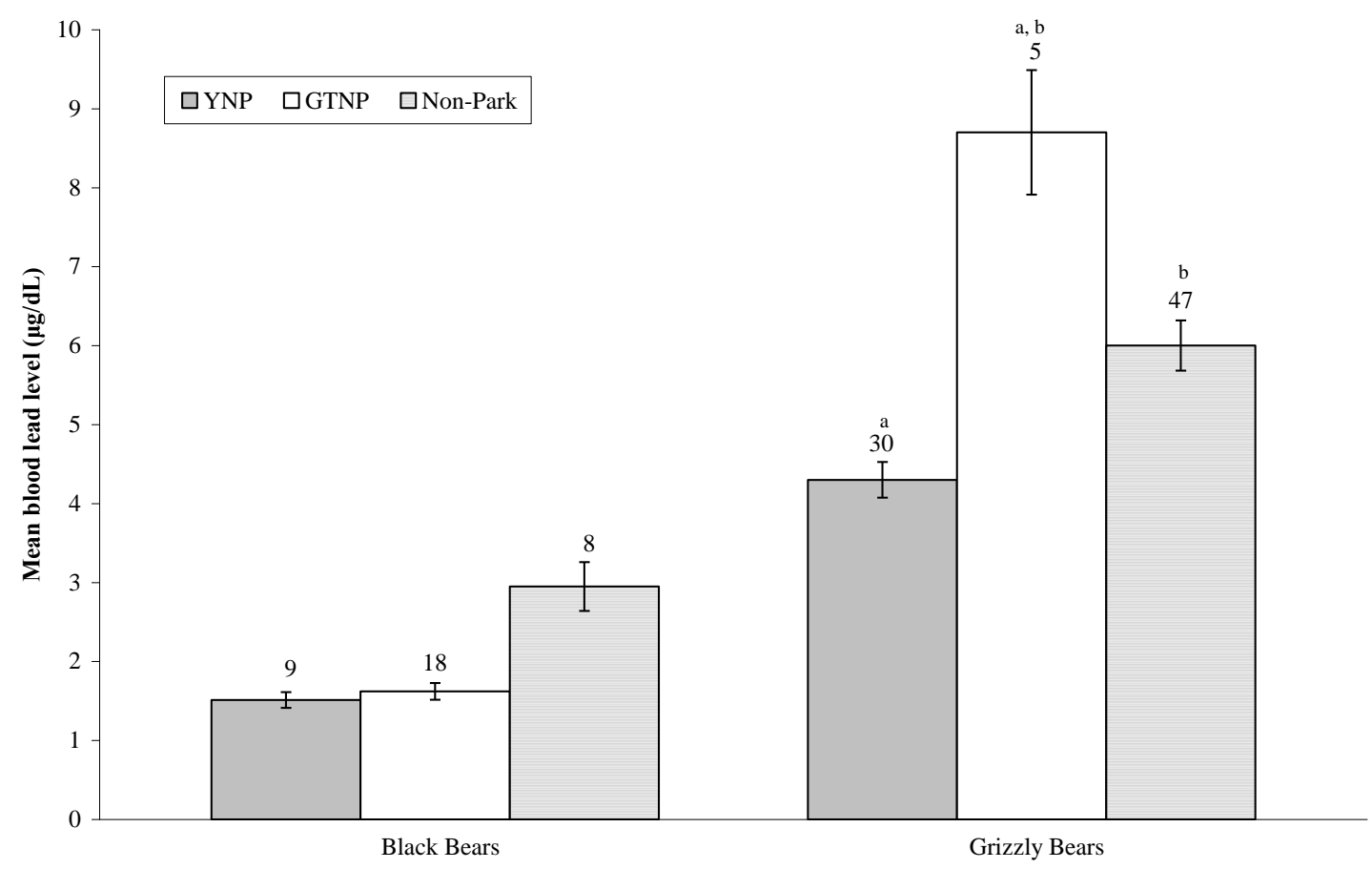

Figure 6. Mean blood lead level (BLLs) in $\mu \mathrm{g} / \mathrm{dL}( \pm \mathrm{SE})$ for grizzly bears and black bears captured in Yellowstone National Park (YNP), Grand Teton National Park (GTNP), and outside either national park (Non-Park). Sample sizes are listed above each bar, and groups with statistically similar BLLs are grouped according to the letters above. YNP is completely closed to hunting while GTNP is open to elk hunting in some parts of the eastern side of the park. The surrounding lands, including private lands, national forest lands, and the National Elk Refuge are mostly open to big game hunting with varying restrictions placed on each. BLLs were similar among YNP, GTNP, and Non-Park black bears $(P=$ 0.69). BLLs were higher for bears captured outside either park than BLLs in grizzly bears captured inside YNP $(P<0.01)$.

\section{Black bears}

I tested BLLs in black bears (Fig. 4) captured in $2007(n=15), 2008(n=14)$, and $2009(n=6)$. There were no significant differences among the three years sampled in a one-way ANOVA $(F=1.117, P=0.21)$, so data from all three years were pooled. Black bears had a median BLL of $1.6 \mu \mathrm{g} / \mathrm{dL}$ and results ranged from 0.5 to $6.9 \mu \mathrm{g} / \mathrm{dL}$. There was no difference in BLLs of black bears captured before $(n=31)$ or during $(n=4)$ the elk hunting season $(F=0.957, P=0.39)$, although the sample size of 4 black bears 
captured during the hunting season may not have been large enough for meaningful statistical comparison.

There was no significant difference in BLLs of male $(n=12)$ and female $(n=23)$ black bears $(F=0.437, P=0.67)$. There was no increase in BLLs with increased age $(F$ $=0.538, P=0.47)$. BLLs in YNP, GTNP, and outside the parks were similar $(P=0.69)$ Fig. 6).

\section{Wolves and cougars}

The wolves tested $(n=12)$ all had BLLs near the bottom of detectible limits (median $=0.5 \mu \mathrm{g} / \mathrm{dL}$, range $=0.0-1.4 \mu \mathrm{g} / \mathrm{dL})$. No blood samples were collected from wolves during the fall elk hunting season. In addition, I tested 9 liver samples from wolves collected between May and August and all were below the limits of detection for lead.

Cougars tested $(n=6)$ also all had BLLs near the bottom of detectible limits $($ median $=1.2 \mu \mathrm{g} / \mathrm{dL}$, range $=0.0-1.4 \mu \mathrm{g} / \mathrm{dL})$. Of the six tested, two were taken from cougars during or immediately following elk hunting season. In addition, I tested 2 liver samples from cougars collected during the hunting season and both were below the limits of detection for lead.

\section{Scat samples}

Scat of grizzly bears, black bears, wolves, and coyotes was collected during the summer $(n=209)$ and fall $(n=214)$ of 2009 . Of the summer subset, 12 were identified as bear scat, 19 as wolf scat, and 149 were below $30 \mathrm{~mm}$ in diameter and were identified as unknown canid scat samples, although it is likely that many of these were coyote scat.

Of the fall subset, 8 were identified as bear scat, 33 as wolf scat, and 168 as unknown 
canid scat samples. I also tested 13 non-hunting season coyote scat samples collected by a collaborating group at the University of Wyoming in 2006.

Additionally, I tested 14 scat samples from grizzly bears captured during the summer, 1 scat sample from a black bear captured during the summer, and 4 grizzly bears captured during the fall hunting season. This scat was collected from the traps when bears were captured for research and management purposes by government agencies.

When digital radiographs of the ground scat samples were analyzed, fragments and shavings of lead ammunition in the control samples were clearly visible. None of the particles in test samples that resembled the clarity and brightness of particles in control samples contained any lead signature upon electron microscopic analysis. Therefore, no lead ammunition fragments were detected in the scat of these large carnivores.

\section{DISCUSSION}

I found that lead levels were highest for grizzly bears, intermediate for black bears, and lowest for cougars and wolves. This supported one of my predictions for patterns I expected to see if animals were ingesting lead ammunition from gut piles based on known differences in carnivore response to big-game hunting (Ruth et al. 2003, Wilmers et al. 2003b, Haroldson et al. 2004) and interspecific interactions between bear species (Belant et al. 2006). In addition, lead levels were higher in grizzly bears and black bears for individuals captured outside YNP as was predicted if ammunition was a source of lead exposure.

However, I did not see a significant increase in BLLs in any species during the fall hunting season after controlling for the trend of increasing lead levels through the whole year. Nor did I see the spike in lead levels in some individuals during the fall 
hunting season characteristic of a population affected by lead ammunition ingestion (Craighead and Bedrosian 2008). In addition, there were no particles of lead ammunition found in the scat, nor were there differences in lead levels for problem grizzly bears and non-problem grizzly bears. There was also no difference in lead levels among the three years sampled despite differences in availability of food sources during these years (Haroldson and Podruzny 2010). In the absence of these trends, I am unable to confirm the hypothesis that grizzly bears or black bears are ingesting lead ammunition. I am unable to determine if wolves or cougars are ingesting lead ammunition due to the scarcity of samples taken from these species during the fall hunting season. However, it is clear that baseline BLLs in wolves and cougars are lower than in grizzly bears in this study area.

In the absence of data describing physiological or behavioral effects of exposure to lead in grizzly bears, it is difficult to assign a specific toxic level of exposure for this species. However, the median BLL in grizzly bears was more than twice as high as levels suggested by Menke et al. (2006) to be safe in humans $(2 \mu \mathrm{g} / \mathrm{dL})$ and some grizzly bears had BLLs that were more than 9 times this benchmark. Lead levels in grizzly bears are also many times higher than the level found in preindustrial humans of $0.016 \mu \mathrm{g} / \mathrm{dL}$ (Flegal and Smith 1992). While it is not currently known what levels of exposure may have detrimental physiological or behavioral effects in grizzly bears, it may be worth further investigation to determine possible point sources of lead exposure for grizzly bears.

Although one single point source of lead exposure is not clear from the patterns in the data, there are a few factors that could potentially be contributing to lead exposure in 
bears. Soil and sediment contaminated with mine tailings have previously contributed to lead exposure in species that directly or indirectly consume soil (Beyer et al. 1997, Blus et al. 1999, Beyer et al. 2007). The GYE contains many current or historical lead mines, particularly in the northeastern and northwestern corners of YNP (Fig. 5). Unlike wolves, coyotes, and cougars which are almost exclusively carnivorous, black bears and grizzly bears are omnivorous, with the majority of their diet consisting of plant matter in the GYE (Robbins et al. 2004). There are several types of food consumed by grizzly bears that may cause them to ingest some soil indirectly when foraging. Yellowstone grizzly bears are known to feed on earthworms (Mattson et al. 2002a), roots (Mattson 1997), mushrooms and truffles (Mattson et al. 2002b). They may also dig up pocket gopher dens and eat both the gopher and its food cache (Mattson 2004). If mine tailings do in fact contribute at least partially to levels of lead exposure seen in bears, this could explain some of the differences in lead exposure between omnivorous bears and the more strictly carnivorous wolves and cougars. Unlike bears, wolves and cougars do not forage for roots and truffles and would therefore not have the potential to be exposed through indirect consumption of soil. However, this would not explain differences observed in BLLs between grizzly bears and black bears.

There are limits to what can be determined about the home range of an individual grizzly bear based on where it was captured because home range sizes for grizzly bears in the GYE average $884 \mathrm{~km}^{2}$ for females and $3757 \mathrm{~km}^{2}$ for males (Blanchard and Knight 1991). Capture location may, however, give a reasonable idea of the general area the bear was located for several days prior to capture because grizzly bears move an average of only 7-8 km per day (Ballard et al. 1982) and often as little as 1-2 km per day 
(Blanchard and Knight 1991). Capture location may therefore be a useful index of areas with higher potential for lead exposure throughout the ecosystem. Lead levels in grizzly bears and black bears are lower inside YNP where there are no mines than outside the park where current and historical lead mines exist. However, there do not appear to be specific clusters of higher lead levels in grizzly bears, while lead mines are clustered in specific areas of the ecosystem (Fig. 5). Therefore, if lead mines are a source of lead exposure in bears, they are likely not the only source. In addition, while there is a statistical difference in levels of exposure to lead in bears captured inside and outside YNP that may give an indication of potential sources of exposure, this difference is not large.

Another potential source of lead exposure may be garbage or paint chips. Lead exposure was higher for black bears and grizzly bears outside of the National Parks where access to garbage for bears might not be as strictly controlled as areas within the parks. BLLs are higher for black bears that were captured for management purposes, which may have been individuals that were removed because they were getting into garbage or coming too close to residential areas. Lead tastes sweet (children purposely ingest lead paint chips because of its taste, Lanphear 1996), so bears may select lead garbage in dumpsters or lead paint chips from old barns or abandoned buildings because of the sweet taste.

While the data I collected do not point to lead ammunition as a point source of lead, they do not strictly exclude this possibility. Wildlife may be exposed to lead from ammunition at times of the year other than hunting season. Non-game animals such as ground squirrels, prairie dogs, and coyotes that are shot with lead ammunition and left in 
the field during times of the year outside of hunting season (Berger 2006) have been proposed as a potential source of lead exposure in scavenging hawks and eagles (Knopper et al. 2006, Pauli and Buskirk 2007, Stephens et al. 2007). If bears are in fact ingesting lead ammunition from these sources, they may not be showing the characteristic spikes in BLLs because they are proportionally so much larger than the size of an ammunition fragment than birds are (a $200 \mathrm{~kg}$ mammal rather than a $1 \mathrm{~kg}$ bird). If ammunition was a major source of exposure, I would likely have detected lead fragments in the scat of these carnivores. However, the lack of detection does not confirm the absence of ammunition fragments in scat.

There is also the potential that grizzly bears and black bears are not being exposed to lead through any particular point source, but are instead exhibiting intrinsically different rates of lead absorption and deposition in the blood than birds and mammals previously tested. While lead exposure for black bears and grizzly bears may be similar to other species tested in this study, they may be exhibiting higher levels of blood lead because of physiological differences in their response to lead exposure. For example, grizzly bears have higher concentrations of persistent organic pollutants in their fat following hibernation compared with before hibernation (Christensen et al. 2007). While lead is not concentrated in fat (Medvedev et al. 1999), hibernation may change other physiological aspects of lead absorption and distribution in the body of bears in other ways. Bears overcome bone loss during disuse while hibernating by maintaining bone formation and resorption during this time (McGee-Lawrence 2009), which would likely mobilize lead stored in bones back into the bloodstream (Gwiazda et al. 2005). While rates of bone turnover during the time period of activity for a bear would be similar to the 
other mammals I've examined, perhaps this process for mitigating bone loss contributes in some way to higher mobilization of lead stores in the bones of bears than in nonhibernating cougars and wolves.

\section{CONCLUSION}

Grizzly bears and black bears show higher BLLs than sympatric carnivores such as wolves and cougars. Grizzly bears and black bears do not exhibit increased BLLs during the fall hunting season, nor do they show spikes in lead levels characteristic of other species known to ingest lead ammunition fragments, and there were no ammunition fragments detected in scat of any of these species. Therefore lead ammunition is likely not the primary source of lead exposure in bears. Other potential point sources may include lead mine tailings, lead-tainted garbage, or possibly lead ammunition fragments from game and non-game species killed with lead ammunition. Lead exposure in bears is higher in less protected areas outside Yellowstone National Park, which may indicate that sources of exposure are more prevalent in these areas. The potential also exists that there are no particular point sources of exposure and environmental lead is simply metabolized differently in bears than other mammals species due to strategies bears employ to mitigate bone loss from disuse during hibernation.

\section{MANAGEMENT IMPLICATIONS}

While it is difficult to establish a specific toxic level of exposure to lead in grizzly bears, BLLs are substantially higher than levels considered safe for humans. It may be in the interest of grizzly bear conservation to mitigate lead exposure because lead negatively affects reproductive rates and intelligence in other species. Grizzly bears reproduce slowly and rely heavily on their intelligence as opportunistic omnivores. If lead toxicity 
affects grizzly bears in ways similar to birds and mammals previously tested, decreased reproduction rates and levels of intelligence due to lead exposure may be hindering grizzly bear recovery.

\section{LITERATURE CITED}

Ackerman, B. B., F. G. Lindzey, and T. P. Hemker. 1984. Cougar Felis concolor food habits in Southern Utah, USA. Journal of Wildlife Management 48:147-155.

Anderson, C. R., Jr., and F. G. Lindzey. 2003. Estimating cougar predation rates from GPS location clusters. Journal of Wildlife Management 67:307-316.

Balagangatharathilagar, M., D. Swarup, R. C. Patra, and S. K. Dwivedi. 2006. Blood lead level in dogs from urban and rural areas of India and its relation to animal and environmental variables. Science of the Total Environment 359:130-134.

Ballard, W. B., S. D. Miller, and T. H. Spraker. 1982. Home range daily movements and reproductive biology of brown bear Ursus arctos in south central Alaska, USA. Canadian Field-Naturalist 96:1-5.

Barry, P. S. I. 1981. Concentrations of lead in the tissues of children. British Journal of Industrial Medicine 38:61-71.

Bedrosian, B., C. N. Parish, and D. Craighead. 2009. Differences between blood lead level detection techniques: Analysis within and among three techniques and four avian species. Extended abstract in R. T. Watson, M. Fuller, M. Pokras, and W. G. Hunt (Eds.). Ingestion of Lead from Spent Ammunition: Implications for Wildlife and Humans. The Peregrine Fund, Boise, Idaho, USA.

Belant, J. L., K. Kielland, E. H. Follmann, and L. G. Adam. 2006. Interspecific resource partitioning in sympatric Ursids. Ecological Applications 16:2333-2343. 
Bellinger, D., J. Sloman, A. Leviton, M. Rabinowitz, H. L. Needleman, and C. Waternaux. 1991. Low-level lead exposure and children's cognitive function in the preschool years. Pediatrics 87:219-227.

Bellrose, F. C. 1959. Lead poisoning as a mortality factor in waterfowl populations. Illinois Natural History Survey Bulletin 27:235-288.

Ben-David, M., K. Titus, and L. R. Beier. 2004. Consumption of salmon by Alaskan brown bears: A trade-off between nutritional requirements and the risk of infanticide? Oecologia (Berlin) 138:465-474.

Berger, K. M. 2006. Carnivore-livestock conflicts: Effects of subsidized predator control and economic correlates on the sheep industry. Conservation Biology 20:751-761.

Bergstrom, B. J., S. Vignieri, S. R. Sheffield, W. Sechrest, and A. A. Carlson. 2009. The Northern Rocky Mountain Gray Wolf Is Not Yet Recovered. Bioscience 59:991999.

Beyer, W. N., L. J. Blus, C. J. Henny, and D. Audet. 1997. The role of sediment ingestion in exposing wood ducks to lead. Ecotoxicology 6:181-186.

Beyer, W. N., G. Gaston, R. Brazzle, A. F. O'Connell, Jr., and D. J. Audet. 2007. Deer exposed to exceptionally high concentrations of lead near the Continental Mine in Idaho, USA. Environmental Toxicology and Chemistry 26:1040-1046.

Blanchard, B. M., and R. R. Knight. 1991. Movements of Yellowstone grizzly bears. Biological Conservation 58:41-68.

Blus, L. J., C. J. Henny, D. J. Hoffman, and R. A. Grove. 1991. Lead toxicosis in tundra swans near a mining and smelting complex in northern Idaho. Archives of Environmental Contamination and Toxicology 21:549-555. 
Blus, L. J., C. J. Henny, D. J. Hoffman, L. Sileo, and D. J. Audet. 1999. Persistence of high lead concentrations and associated effects in tundra swans captured near a mining and smelting complex in northern Idaho. Ecotoxicology 8:125-132.

Blus, L. J., R. K. Stroud, B. Reiswig, and T. McEneaney. 1989. Lead poisoning and other mortality factors in trumpeter swans. Environmental Toxicology and Chemistry 8:263-271.

Buerger, T. T., R. W. Mirarchi, and M. E. Lisano. 1986. Effects of lead shot ingestion on captive mourning dove survivability and reproduction. Journal of Wildlife Management 50:1-8.

Burger, J. 1998. Effects of lead on sibling recognition in young herring gulls. Toxicological Sciences 43:155-160.

Burger, J., and M. Gochfeld. 1997. Lead and neurobehavioral development in gulls: A model for understanding effects in the laboratory and the field. Neurotoxicology (Little Rock) 18:495-506.

2000. Effects of lead on birds (Laridae): A review of laboratory and field studies. Journal of Toxicology and Environmental Health Part B Critical Reviews 3:5978.

2005. Effects of lead on learning in herring gulls: An avian wildlife model for neurobehavioral deficits. Neurotoxicology (Amsterdam) 26:615-624.

Cade, T. J. 2007. Exposure of California condors to lead from spent ammunition. Journal of Wildlife Management 71:2125-2133.

Calvert, J. H. 1873. Pheasants poisoned by swallowing shots. The Field 47:189.

Callender, E., and P. C. Van Metre. 1997. Reservoir sediment cores show U.S. lead 
declines. Environmental Science and Technology 31:424A-428A.

Carson, E. A., V. H. Stefan, and J. F. Powell. 2000. Skeletal manifestations of bear scavenging. Journal of Forensic Sciences 45:515-526.

Celechovska, O., I. Literak, S. Ondrus, and Z. Pospisil. 2006. Heavy metals in brown bears from the central European Carpathians. Acta Veterinaria Brno 75:501-506.

Charlton, K. G., D. W. Hird, and L. K. Spiegel. 2001. Trace metal concentrations in San Joaquin kit foxes from the southern San Joaquin Valley of California. California Fish and Game 87:45-50.

Christensen, J. R., M. MacDuffee, M. B. Yunker, and P. S. Ross. 2007. Hibernationassociated changes in persistent organic pollutant (POP) levels and patterns in British Columbia grizzly bears (Ursus arctos horribilis). Environmental Science \& Technology 41:1834-1840.

Chupp, N. R., and P. D. Dalke. 1964. Waterfowl mortality in the Coeur d'Alene River Valley, Idaho. Journal of Wildlife Management 28:692-702.

Church, M. E., R. Gwiazda, R. W. Risebrough, K. Sorenson, C. P. Chamberlain, S. Farry, W. Heinrich, B. A. Rideout, and D. R. Smith. 2006. Ammunition is the principal source of lead accumulated by California Condors re-introduced to the wild. Environmental Science and Technology 40:6143-6150.

Clark, A. J., and A. M. Scheuhammer. 2003. Lead poisoning in upland-foraging birds of prey in Canada. Ecotoxicology 12:23-30.

Cook, W. E., E. S. Williams, and S. A. Dubay. 2004. Disappearance of bovine fetuses in northwestern Wyoming. Wildlife Society Bulletin 32:254-259.

Craighead, D., and B. Bedrosian. 2008. Blood lead levels of common ravens with access 
to big-game offal. Journal of Wildlife Management 72:240-245.

DeVault, T. L., O. E. Rhodes, Jr., and J. A. Shivik. 2003. Scavenging by vertebrates: Behavioral, ecological, and evolutionary perspectives on an important energy transfer pathway in terrestrial ecosystems. Oikos 102:225-234.

Dinius, D. A., T. H. Brinsfield, and E. E. Williams. 1973. Effect of subclinical lead intake on calves. Journal of Animal Science 37:169-173.

Dip, R., C. Stieger, P. Deplazes, D. Hegglin, U. Muller, O. Dafflon, H. Koch, and H. Naegeli. 2001. Comparison of heavy metal concentrations in tissues of red foxes from adjacent urban, suburban, and rural areas. Archives of Environmental Contamination and Toxicology 40:551-556.

Domenech, R., and H. Langner. 2009. Blood-lead levels of fall migrant Golden Eagles in west-central Montana. Extended abstract in R. T. Watson, M. Fuller, M. Pokras, and W. G. Hunt (Eds.). Ingestion of Lead from Spent Ammunition: Implications for Wildlife and Humans. The Peregrine Fund, Boise, Idaho, USA.

Ettinger, A. S., M. M. Tellez-Rojo, C. Amarasiriwardena, D. Bellinger, K. Peterson, J. Schwartz, H. Hu, and M. Hernandez-Avila. 2004. Effect of breast milk lead on infant blood lead levels at 1 month of age. Environmental Health Perspectives 112:1381-1385.

Fine, B. P., T. Vetrano, J. Skurnick, and A. Ty. 1988. Blood pressure elevation in young dogs during low-level lead poisoning. Toxicology and Applied Pharmacology 93:388-393.

Finkelstein, M. E., R. H. Gwiazda, and D. R. Smith. 2003. Lead poisoning of seabirds: Environmental risks from leaded paint at a decommissioned military base. 
Environmental Science and Technology 37:3256-3260.

Fisher, I. J., D. J. Pain, and V. G. Thomas. 2006. A review of lead poisoning from ammunition sources in terrestrial birds. Biological Conservation 131:421-432.

Flegal, A. R., and D. R. Smith. 1992. Lead levels in preindustrial humans. New England Journal of Medicine 326:1293-1294.

Flint, P. L., and J. L. Schamber. 2010. Long-term persistence of spent lead shot in tundra wetlands. Journal of Wildlife Management 74:148-151.

Franson, J. C., S. P. Hansen, T. E. Creekmore, C. J. Brand, D. C. Evers, A. E. Duerr, and S. DeStefano. 2003. Lead fishing weights and other fishing tackle in selected waterbirds. Waterbirds 26:345-352.

Gangoso, L., P. Alvarez-Lloret, A. A. B. Rodriguez-Navarro, R. Mateo, F. Hiraldo, and J. Antonio Donazar. 2009. Long-term effects of lead poisoning on bone mineralization in vultures exposed to ammunition sources. Environmental Pollution 157:569-574.

Ghisleni, G., V. Spagnolo, P. Roccabianca, E. Scanziani, S. Paltrinieri, F. Lupo, E. Ferretti, and F. Nageli. 2004. Blood lead levels, clinico-pathological findings and erythrocyte metabolism in dogs from different habitats. Veterinary and Human Toxicology 46:57-61.

Gluckman, P. D., and M. A. Hanson. 2004. Living with the past: Evolution, development, and patterns of disease. Science (Washington D C) 305:1733-1736.

Goyer, R. A. 1993. Lead toxicity: Current concerns. Environmental Health Perspectives 100:177-187.

Green, G. I., D. J. Mattson, and J. M. Peek. 1997. Spring feeding on ungulate carcasses 
by grizzly bears in Yellowstone National Park. Journal of Wildlife Management 61:1040-1055.

Green, R. E., W. G. Hunt, C. N. Parish, and I. Newton. 2008. Effectiveness of Action to Reduce Exposure of Free-Ranging California Condors in Arizona and Utah to Lead from Spent Ammunition. PLoS One 3:Article No.: e4022.

Grinnell, G. B. 1894. Lead poisoning. Forest and Stream 42:117-118.

Gwiazda, R., C. Campbell, and D. Smith. 2005. A noninvasive isotopic approach to estimate the bone lead contribution to blood in children: Implications for assessing the efficacy of lead abatement. Environmental Health Perspectives 113:104-110.

Hacker, H. J., P. Bannasch, and A. Columbano. 1990. Effect of lead nitrate on liver carbohydrate enzymes and glycogen content in the rat. Carcinogenesis (Oxford) 11:2199-2204.

Halfpenny, J. C. 2001. Scat and Tracks of the Northern Rocky Mountains. Falcoln, USA. Hamilton, J. D., and E. J. O'Flaherty. 1995. Influence of lead on mineralization during bone growth. Fundamental and Applied Toxicology 26:265-271.

Hamir, A. N., N. D. Sullivan, and P. D. Handson. 1984. Neuropathological lesions in experimental lead toxicosis of dogs. Journal of Comparative Pathology 94:215232.

Hamir, A. N., N. D. Sullivan, P. D. Handson, J. S. Wilkinson, and R. B. Lavelle. 1981. Clinical signs, radiology, and tissue lead distribution of dogs administered a mixture of lead chloride, lead bromide, and lead sulfate. Australian Veterinary Journal 57:401-406. 
Haroldson, M. A., C. C. Schwartz, S. Cherry, and D. S. Moody. 2004. Possible effects of elk harvest on fall distribution of grizzly bears in the Greater Yellowstone Ecosystem. Journal of Wildlife Management 68:129-137.

Haroldson, M. A. and S. Podruzny. 2010. Whitebark pine cone production. 2009 Project Summary, USGS, Northern Rocky Mountain Science Center, Interagency Grizzly Bear Study Team. Bozeman, MT.

Henny, C. J., L. J. Blus, D. J. Hoffman, R. A. Grove, and J. S. Hatfield. 1991. Lead accumulation and osprey production near a mining site on the Couer d'Alene River Idaho, USA. Archives of Environmental Contamination and Toxicology 21:415-424.

Henny, C. J., L. J. Blus, D. J. Hoffmann, and R. A. Grove. 1994. Lead in hawks, falcons and owls downstream from a mining site on the Coeur D'Alene River, Idaho. Environmental Monitoring and Assessment 29:267-288.

Holdner, J., B. Wainman, R. Jaysinghe, E. Van Spronsen, J. D. Karagatzides, E. Nieboer, and L. J. S. Tsuji. 2004. Soil and plant lead of upland habitat used extensively for recreational shooting and game bird hunting in southern Ontario, Canada. Bulletin of Environmental Contamination and Toxicology 73:568-574.

Hunt, W. G., W. Burnham, C. N. Parish, K. K. Burnham, B. Mutch, and J. L. Oaks. 2006. Bullet fragments in deer remains: Implications for lead exposure in avian scavengers. Wildlife Society Bulletin 34:167-170.

Hunt, W. G., R. T. Watson, J. L. Oaks, C. N. Parish, K. K. Burnham, R. L. Tucker, J. R. Belthoff, and G. Hart. 2009. Lead Bullet Fragments in Venison from Rifle-Killed Deer: Potential for Human Dietary Exposure. PLoS One 4:Article No.: e5330. 
[IUCN] International Union for the Conservation of Nature. 2010. The IUCN Redlist of Threatened Species. IUCN. (26 February 2010, http://www.iucnredlist.org/).

Jacks, G., M. Bystrom, and L. Johansson. 2001. Lead emissions from lost fishing sinkers. Boreal Environment Research 6:231-236.

Jannsen, D. J., J. E. Oosterhuis, J. L. Allen, M. P. Anderson, D. G. Kelts, S. N. Weinmeyer. 1986. Lead Poisoning in free-ranging California condors. Journal of American Veterinary Medical Association 189(9):1115-1117.

Jennelle, C. S., M. D. Samuel, C. A. Nolden, D. P. Keane, D. J. Barr, C. Johnson, J. P. Vanderloo, J. M. Aiken, A. N. Hamir, and E. A. Hoover. 2009. Surveillance for Transmissible Spongiform Encephalopathy in Scavengers of White-Tailed Deer Carcasses in the Chronic Wasting Disease Area of Wisconsin. Journal of Toxicology and Environmental Health Part A 72:1018-1024.

Johansen, P., G. Asmund, and F. Riget. 2001. Lead contamination of seabirds harvested with lead shot: Implications to human diet in Greenland. Environmental Pollution 112:501-504

Kannan, K., T. Agusa, T. J. Evans, and S. Tanabe. 2007. Trace element concentrations in livers of polar bears from two populations in Northern and Western Alaska. Archives of Environmental Contamination and Toxicology 53:473-482.

Kasworm, W. F., M. F. Proctor, C. Servheen, and D. Paetkau. 2007. Success of grizzly bear population augmentation in northwest Montana. Journal of Wildlife Management 71:1261-1266.

Kendall, K. C., L. H. Metzgar, D. A. Patterson, and B. M. Steele. 1992. Power of sign surveys to monitor population trends. Ecological Applications 2:422-430. 
Kendall, R. J., T. E. Lacher, Jr., C. Bunck, B. Daniel, C. Driver, C. E. Grue, F. Leighton, W. Stansley, P. G. Watanabe, and M. Whitworth. 1996. An ecological risk assessment of lead shot exposure in non-waterfowl avian species: Upland game birds and raptors. Environmental Toxicology and Chemistry 15:4-20.

Knopper, L. D., P. Mineau, A. M. Scheuhammer, D. E. Bond, and D. T. McKinnon. 2006. Carcasses of shot Richardson's ground squirrels may pose lead hazards to scavenging hawks. Journal of Wildlife Management 70:295-299.

Koh, T. S., and P. J. Babidge. 1986. A comparison of blood lead levels in dogs from a lead-mining lead smelting urban and rural island environment. Australian Veterinary Journal 63:282-285.

Laliberte, A. S., and W. J. Ripple. 2004. Range contractions of North American carnivores and ungulates. Bioscience 54:123-138.

Lanphear, B. P., D. A. Burgoon, S. W. Rust, S. Eberly, and W. Galke. 1998. Environmental exposures to lead and urban children's blood lead levels. Environmental Research 76:120-130.

Lanphear, B. P., M. Weitzman, and S. Eberly. 1996. Racial differences in urban children's environmental exposure to lead. American Journal of Public Health 86:1460-1463.

Locke, L. N., S. M. Kerr, and D. Zoromski. 1982. Lead poisoning in common loons (Gavia immer). Avian Diseases 26:392-396.

Lopez-Alonso, M., M. Miranda, P. Garcia-Partida, A. Mendez, C. Castillo, and J. L. Benedito. 2007. Toxic and trace metal concentrations in liver and kidney of dogs Influence of diet, sex, age, and pathological lesions. Biological Trace Element 
Research 116:185-202.

Lustberg, M., and E. Silbergeld. 2002. Blood lead levels and mortality. Archives of Internal Medicine 162:2443-2449.

Magoun, A. J. 1976. Summer scavenging activity in northeastern Alaska. - M. S. thesis, University of Alaska, Fairbanks, AK, USA.

Markovac, J., and G. W. Goldstein. 1988. Picomolar concentrations of lead stimulate brain protein kinase C. Nature (London) 334:71-73.

Martin, P. A., D. Campbell, and A. Scheuhammer. 2003. Lead exposure in terrestrial foraging raptors in southern Ontario, 1999 - 2001. IAGLR Conference Program and Abstracts 46:269.

Martin, P. A., D. Campbell, K. Hughes, and T. McDaniel. 2008. Lead in the tissues of terrestrial raptors in southern Ontario, Canada, 1995-2001. Science of the Total Environment 391:96-103.

Martinez-Haro, M., M. A. Taggart, A. J. Green, and R. Mateo. 2009. Avian Digestive Tract Simulation To Study the Effect of Grit Geochemistry and Food on Pb Shot Bioaccessibility. Environmental Science \& Technology 43:9480-9486.

Mateo, R., A. J. Green, H. Lefranc, R. Baos, and J. Figuerola. 2007a. Lead poisoning in wild birds from southern Spain: A comparative study of wetland areas and species affected, and trends over time. Ecotoxicology and Environmental Safety 66:119126.

Mateo, R., M. Rodriguez-de la Cruz, D. Vidal, M. Reglero, and P. Camarero. 2007b. Transfer of lead from shot pellets to game meat during cooking. Science of the Total Environment 372:480-485. 
Mattson, D. J. 1997. Selection of microsites by grizzly bears to excavate biscuitroots. Journal of Mammalogy 78:228-238. . 2004. Exploitation of pocket gophers and their food caches by grizzly bears. Journal of Mammalogy 85:731-742.

Mattson, D. J., M. G. French, and S. P. French. 2002a. Consumption of earthworms by Yellowstone grizzly bears. Ursus (Knoxville) 13:105-110.

Mattson, D. J., S. R. Podruzny, and M. A. Haroldson. 2002b. Consumption of fungal sporocarps by Yellowstone grizzly bears. Ursus (Knoxville) 13:95-103.

McGee-Lawrence, M. E., S. J. Wojda, L. N. Barlow, T. D. Drummer, A. B. Castillo, O. Kennedy, K. W. Condon, J. Auger, H. L. Black, O. L. Nelson, C. T. Robbins, and S. W. Donahue. 2009. Grizzly bears (Ursus arctos horribilis) and black bears (Ursus americanus) prevent trabecular bone loss during disuse (hibernation). Bone (New York) 45:1186-1191.

Medvedev, N. 1999. Levels of heavy metals in Karelian wildlife, 1989-91. Environmental Monitoring and Assessment 56:177-193.

Menke, A., P. Muntner, V. Batuman, E. K. Silbergeld, and E. Guallar. 2006. Blood lead below $0.48 \mathrm{mu} \mathrm{mol} / \mathrm{L}(10 \mathrm{mu} \mathrm{g} / \mathrm{dL})$ and mortality among US adults. Circulation 114:1388-1394.

Millan, J., R. Mateo, M. A. Taggart, J. V. Lopez-Bao, M. Viota, L. Monsalve, P. R. Camarero, E. Blazquez, and B. Jimenez. 2008. Levels of heavy metals and metalloids in critically endangered Iberian lynx and other wild carnivores from Southern Spain. Science of the Total Environment 399:193-201.

Miranda, M., M. Lopez-Alonso, P. Garcia-Partida, J. Velasco, and J. L. Benedito. 2006. 
Long-term follow-up of blood lead levels and haematological and biochemical parameters in heifers that survived an accidental lead poisoning episode. Journal of Veterinary Medicine Series A 53:305-310.

Magoun, A. J. 1976. Summer scavenging activity in northeastern Alaska. - M. S. thesis, University of Alaska, Fairbanks, AK, USA.

Navas-Acien, A., E. Guallar, E. K. Silbergeld, and S. J. Rothenberg. 2007. Lead exposure and cardiovascular disease - A systematic review. Environmental Health Perspectives 115:472-482.

Neumann, K. 2009. Bald Eagle lead poisoning in winter. In R. T. Watson, M. Fuller, M. Pokras, and W. G. Hunt (Eds.). Ingestion of Lead from Spent Ammunition: Implications for Wildlife and Humans. The Peregrine Fund, Boise, Idaho, USA.

Norheim, G., J. U. Skaare, and O. Wiig. 1992. Some heavy metals essential elements and chlorinated hydrocarbons in polar bear (Ursus maritimus) at Svalbard. Environmental Pollution 77:51-57.

Nriagu, J. O. 1990. The rise and fall of leaded gasoline. Science of the Total Environment 92:13-28.

Oluokun, J. A., A. K. Fajimi, A. O. Adebayo, and F. T. Ajayi. 2007. Lead and cadmium poisoning of goats raised in cement kiln dust polluted area. Journal of Food Agriculture \& Environment 5:382-384.

Osman, K., K. Pawlas, A. Schutz, M. Gazdzik, J. A. Sokal, and M. Vahter. 1999. Lead exposure and hearing effects in children in Katowice, Poland. Environmental Research 80:1-8.

Pauli, J. N., and S. W. Buskirk. 2007. Recreational shooting of prairie dogs: A portal for 
lead entering wildlife food chains. Journal of Wildlife Management 71:103-108.

Potts, G. R. 2005. Incidence of ingested lead gunshot in wild grey partridges (Perdix perdix) from the UK. European Journal of Wildlife Research 51:31-34.

Robbins, C. T., C. C. Schwartz, and L. A. Felicetti. 2004. Nutritional ecology of ursids: a review of newer methods and management implications. Ursus (Knoxville) 15:161-171.

Rodrigue, J., R. McNicoll, D. Leclair, and J. F. Duchesne. 2005. Lead concentrations in ruffed grouse, rock ptarmigan, and willow ptarmigan in Quebec. Archives of Environmental Contamination and Toxicology 49:97-104.

Rosen, T. 2007. The Endangered Species Act and the distinct population segment policy. Ursus (Knoxville) 18:109-116.

Rush, S. A., K. Borga, R. Dietz, E. W. Born, C. Sonne, T. Evans, D. C. G. Muir, R. J. Letcher, R. J. Norstrom, and A. T. Fisk. 2008. Geographic distribution of selected elements in the livers of polar bears from Greenland, Canada and the United States. Environmental Pollution 153:618-626.

Ruth, T. K., D. W. Smith, M. A. Haroldson, P. C. Buotte, C. C. Schwartz, H. B. Quigley, S. Cherry, K. M. Murphy, D. Tyers, and K. Frey. 2003. Large-carnivore response to recreational big-game hunting along the Yellowstone National Park and Absaroka-Beartooth Wilderness boundary. Wildlife Society Bulletin 31:11501161.

Scheuhammer, A. M., and S. L. Norris. 1996. The ecotoxicology of lead shot and lead fishing weights. Ecotoxicology 5:279-295.

Schnaas, L., S. J. Rothenberg, M.-F. Flores, S. Martinez, C. Hernandez, E. Osorio, S. R. 
Velasco, and E. Perroni. 2006. Reduced intellectual development in children with prenatal lead exposure. Environmental Health Perspectives 114:791-797.

Schulz, J. H., X. Gao, J. J. Millspaugh, and A. J. Bermudez. 2007. Experimental lead pellet ingestion in mourning doves (Zenaida macroura). American Midland Naturalist 158:177-190.

Schulz, J. H., J. J. Millspaugh, A. J. Bermudez, X. Gao, T. W. Bonnot, L. G. Britt, and M. Paine. 2006. Acute lead toxicosis in mourning doves. Journal of Wildlife Management 70:413-421.

Schwartz, C. C., M. A. Haroldson, G. C. White, R. B. Harris, S. Cherry, K. A. Keating, D. Moody, and C. Servheen. 2006. Temporal, spatial, and environmental influences on the demographics of grizzly bears in the Greater Yellowstone Ecosystem. Wildlife Monographs 161:1-68.

Sharma, R. P., J. C. Street, J. L. Shupe, and D. R. Bourcier. 1982. Accumulation and depletion of cadmium and lead in tissues and milk of lactating cows fed small amounts of these metals. Journal of Dairy Science 65:972-979.

Sileo, L., L. H. Creekmore, D. J. Audet, M. R. Snyder, C. U. Meteyer, J. C. Franson, L. N. Locke, M. R. Smith, and D. L. Finley. 2001. Lead poisoning of waterfowl by contaminated sediment in the Coeur d'Alene River. Archives of Environmental Contamination and Toxicology 41:364-368.

Smith, B. L., and S. H. Anderson. 1998. Juvenile survival and population regulation of the Jackson elk herd. Journal of Wildlife Management 62:1036-1045.

Smith, D. M., Jr., H. W. Mielke, and J. B. Heneghan. 2008. Subchronic lead feeding study in male rats. Archives of Environmental Contamination and Toxicology 
$55: 518-528$.

Spears, B. L., J. A. Hansen, and D. J. Audet. 2007. Blood lead concentrations of waterfowl utilizing Lake Coeur d'Alene, Idaho. Archives of Environmental Contamination and Toxicology 52:121-128.

Stephens, R. M., A. S. Johnson, R. E. Plumb, K. Dickerson, and M. C. McKinstry. 2007. Risk assessment of lead poisoning in raptors caused by recreational shooting of prairie dogs. Intermountain Journal of Sciences 13:116-123.

Todorovic, T., D. Vujanovic, I. Dozic, and A. Petkovic-Curcin. 2008. Calcium and magnesium content in hard tissues of rats under condition of subchronic lead intoxication. Magnesium Research 21:43-50.

Tsuji, L. J. S., B. C. Wainman, R. K. Jayasinghe, E. P. VanSpronsen, and E. N. Liberda. 2009. Determining Tissue-Lead Levels in Large Game Mammals Harvested with Lead Bullets: Human Health Concerns. Bulletin of Environmental Contamination and Toxicology 82:435-439.

Tsuji, L. J. S., B. C. Wainman, I. D. Martin, C. Sutherland, J.-P. Weber, P. Dumas, and E. Nieboer. 2008a. Lead shot contribution to blood lead of First Nations people: The use of lead isotopes to identify the source of exposure. Science of the Total Environment 405:180-185.

. 2008b. The identification of lead ammunition as a source of lead exposure in First Nations: The use of lead isotope ratios. Science of the Total Environment 393:291-298.

Tsuji, L. J. S., B. C. Wainman, I. D. Martin, J. P. Weber, C. Sutherland, E. N. Liberda, and E. Nieboer. 2008c. Elevated blood-lead levels in First Nation people of 
northern Ontario Canada: Policy implications. Bulletin of Environmental Contamination and Toxicology 80:14-18.

Tsuji, L. J. S., and J. D. Karagatzides. 1998. Spent lead shot in the western James bay region of northern Ontario, Canada: Soil and plant chemistry of a heavily hunted wetland. Wetlands 18:266-271.

[USFWS] US Fish and Wildlife Service. 2010. Species Reports Listing Status. USFWS. (26 February 2010, http://ecos. fws.gov/tess_public/ SpeciesReport.do)

Wayland, M., and T. Bollinger. 1999. Lead exposure and poisoning in bald eagles and golden eagles in the Canadian prairie provinces. Environmental Pollution 104:341-350.

Weaver, J. L. 1979. Comparison of coyote and wolf scat diameters. Journal of Wildlife Management 43:786-788.

White, L. D., D. A. Cory-Slechta, M. E. Gilbert, E. Tiffany-Castiglioni, N. H. Zawia, M. Virgolini, A. Rossi-George, S. M. Lasley, Y. C. Qian, and M. R. Basha. 2007. New and evolving concepts in the neurotoxicology of lead. Toxicology and Applied Pharmacology 225:1-27.

Wiemeyer, S. N., R. M. Jurek, and J. F. Moore. 1986. Environmental contaminants in surrogates, foods, and feathers of California condors (Gymnogyps californianus). Environmental Monitoring and Assessment 6:91-111.

Wiemeyer, S. N., J. M. Scott, M. P. Anderson, P. H. Bloom, and C. J. Stafford. 1988. Environmental contaminants in California condors. Journal of Wildlife Management 52:238-247.

Wilmers, C. C., R. L. Crabtree, D. W. Smith, K. M. Murphy, and W. M. Getz. 2003a. 
Trophic facilitation by introduced top predators: Grey wolf subsidies to scavengers in Yellowstone National Park. Journal of Animal Ecology 72:909-916.

Wilmers, C. C., D. R. Stahler, R. L. Crabtree, D. W. Smith, and W. M. Getz. 2003 b. Resource dispersion and consumer dominance: Scavenging at wolf- and hunterkilled carcasses in Greater Yellowstone, USA. Ecology Letters 6:996-1003.

Woshner, V. M., T. M. O'Hara, G. R. Bratton, and V. R. Beasley. 2001. Concentrations and interactions of selected essential and non-essential elements in ringed seals and polar bears of arctic Alaska. Journal of Wildlife Diseases 37:711-721.

Wu, J., M. R. Basha, B. Brock, D. P. Cox, F. Cardozo-Pelaez, C. A. McPherson, J. Harry, D. C. Rice, B. Maloney, D. Chen, D. K. Lahiri, and N. H. Zawia. 2008. Alzheimer's disease (AD)-like pathology in aged monkeys after infantile exposure to environmental metal lead (pb): Evidence for a developmental origin and environmental link for AD. Journal of Neuroscience 28:3-9.

Wynne, J., and C. Stringfield. 2007. Treatment of lead toxicity and crop stasis in a California condor (Gymnogyps californianus). Journal of Zoo and Wildlife Medicine 38:588-590. 


\section{APPENDIX}

In a simple linear regression, there was no correlation between time after collection until analysis and BLL $\left(\mathrm{F}=1.16, P=0.285, R^{2}=0.01\right)$. Therefore, time after analysis does not appear to have an effect on the result.

In order to confirm the accuracy of analysis using the ESA Leadcare ${ }^{\circledR}$ system (LCS) for samples run up to a year after collection, I took 15 grizzly bear blood samples previously run on LCS and reran them at different time intervals. This retest included samples that originally had readings that were relatively low, medium, and high BLL measured for grizzly bears. These samples were rerun one year after the initial run date $(n=8), 1-3$ weeks after the initial run date $(n=6)$, or immediately after the initial run $(n$ $=1)$.

There was one extreme outlier $(13.3 \mu \mathrm{g} / \mathrm{dL}$ lower than the original), which I reran immediately and came out with the exact same answer again $(13.3 \mu \mathrm{g} / \mathrm{dL}$ lower $)$. This could have been a result of human error or of process error during the initial test, which does happen rarely in many different forms of testing blood lead levels (Bedrosian et al. 2009). The mean difference between the values during the initial test and the values measured during the retest including the outlier was $-1.8 \mu \mathrm{g} / \mathrm{dL}(P<0.01)$. However, because this was an extreme outlier (Fig. 7), I chose to remove it from further analysis because I believed this was the best way to determine the true trend of the difference between initial values and retest values.

Across all samples, fourteen out of the 15 values were very close to the original value during the retest, although they were generally slightly lower (mean $=-0.9 \mu \mathrm{g} / \mathrm{dL}$, 
95\% CI $(-1.5,-0.4) \mu \mathrm{g} / \mathrm{dL}, P=0.01)$. The formula for this trend between the first and second runs was $y=0.9005 x-0.165$ and the correlation was strong $\left(R^{2}=0.98\right.$, Fig. 8).

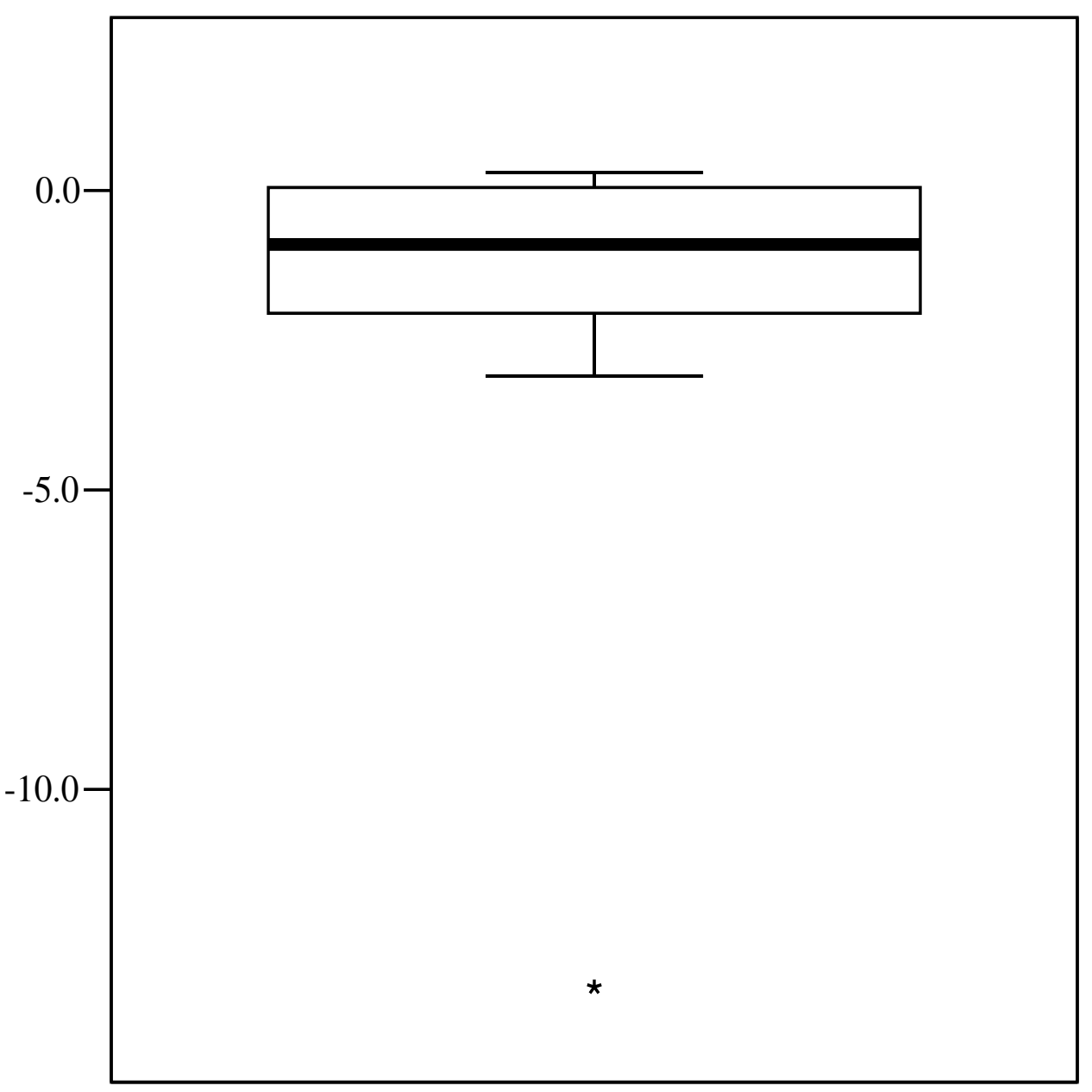

Figure 7. Boxplot of the difference between values tested initially using the LCS and values measured during the retest. Values during the retest were generally slightly lower $(-1.8 \mu \mathrm{g} / \mathrm{dL}, P<0.01)$ with one extreme outlier $13.3 \mu \mathrm{g} / \mathrm{dL}$ below the original measurement.

Among samples run one year later $(n=7)$, however, the mean difference was $-1.0 \mu \mathrm{g} / \mathrm{dL}$ $(P=0.18)$ and the $95 \%$ confidence interval was $(-2.0,0.0) \mu \mathrm{g} / \mathrm{dL}$, so this difference was not significant. The formula for this trend between the values measured initially and the values measured one year later was $\mathrm{y}=0.8372 \mathrm{x}-0.0188$ and the correlation was again 
strong $\left(R^{2}=0.96\right.$, Fig. 9). Therefore, time between the collection and analysis of samples may not strongly affect the result.

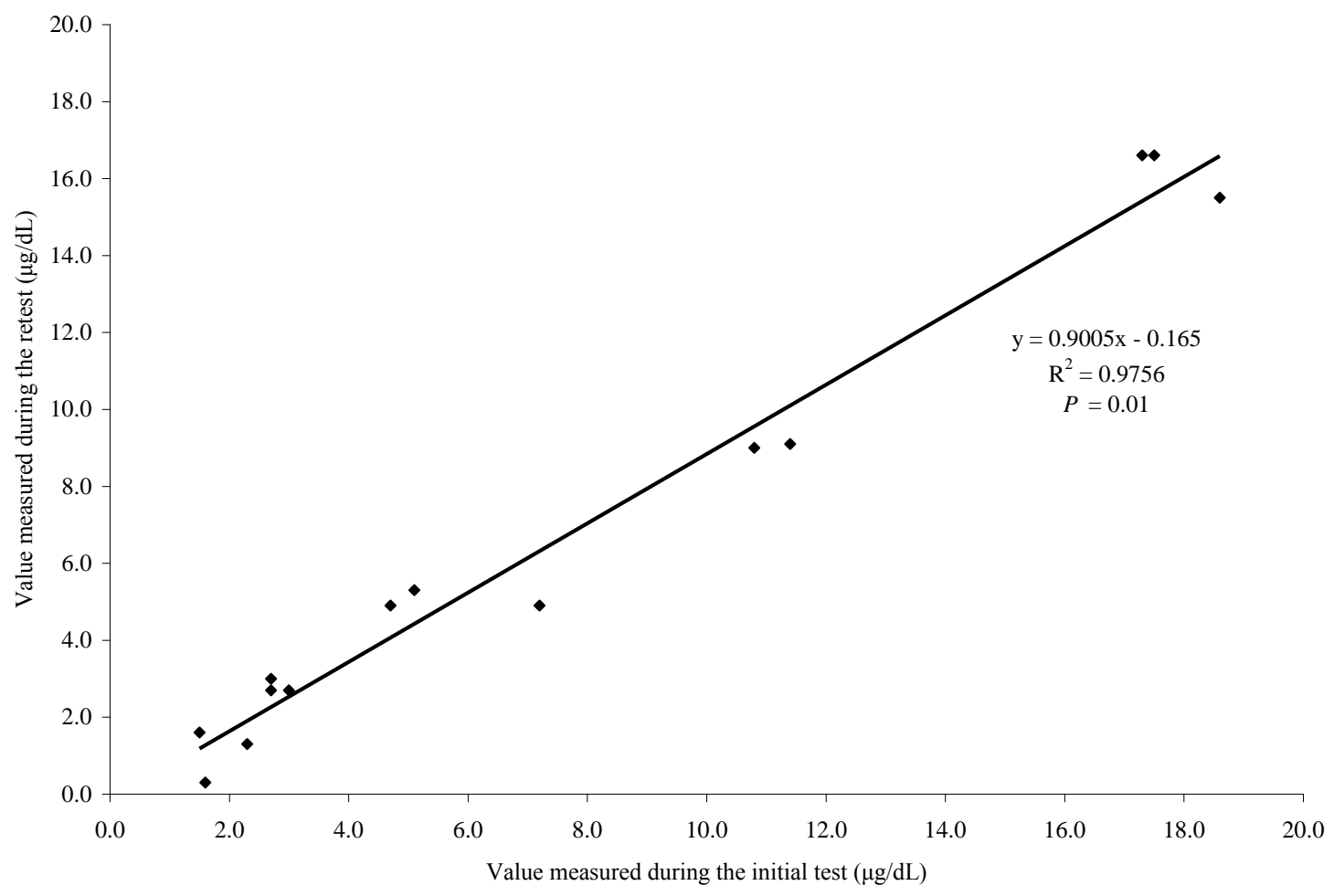

Figure 8. Difference between the value measured during the initial test and the value measured during the retest using LCS. The values measured during the retest were slightly lower than values measured during the initial test $(P=0.01)$. This difference was $-0.9 \mu \mathrm{g} / \mathrm{dL}$ and was within normal range of variation defined by ESA for the control blood samples.

Therefore, we can conclude that like other forms of sampling, there are occasional errors in values given. While there may be a slight decrease in lead levels for samples tested after a year of storage, this difference was not statistically significant, nor would it greatly change the trend in the data. This may also explain the slight increase in lead levels throughout the year, as samples taken early in the year might be very slightly higher than actual values measured. All samples are tested at the end of the year, 
whereas samples taken later in the year would be tested closer to the time they were extracted from the bear. However, I controlled for this trend of slightly rising lead levels throughout the year when testing for a difference between before hunting season and during hunting season lead levels by doing a segmented regression. Time between collection and analysis was included as a co-variable in when comparing populations from GTNP, YNP, and outside the park. Therefore, if there is an effect of time until analysis on results, this effect was controlled for.

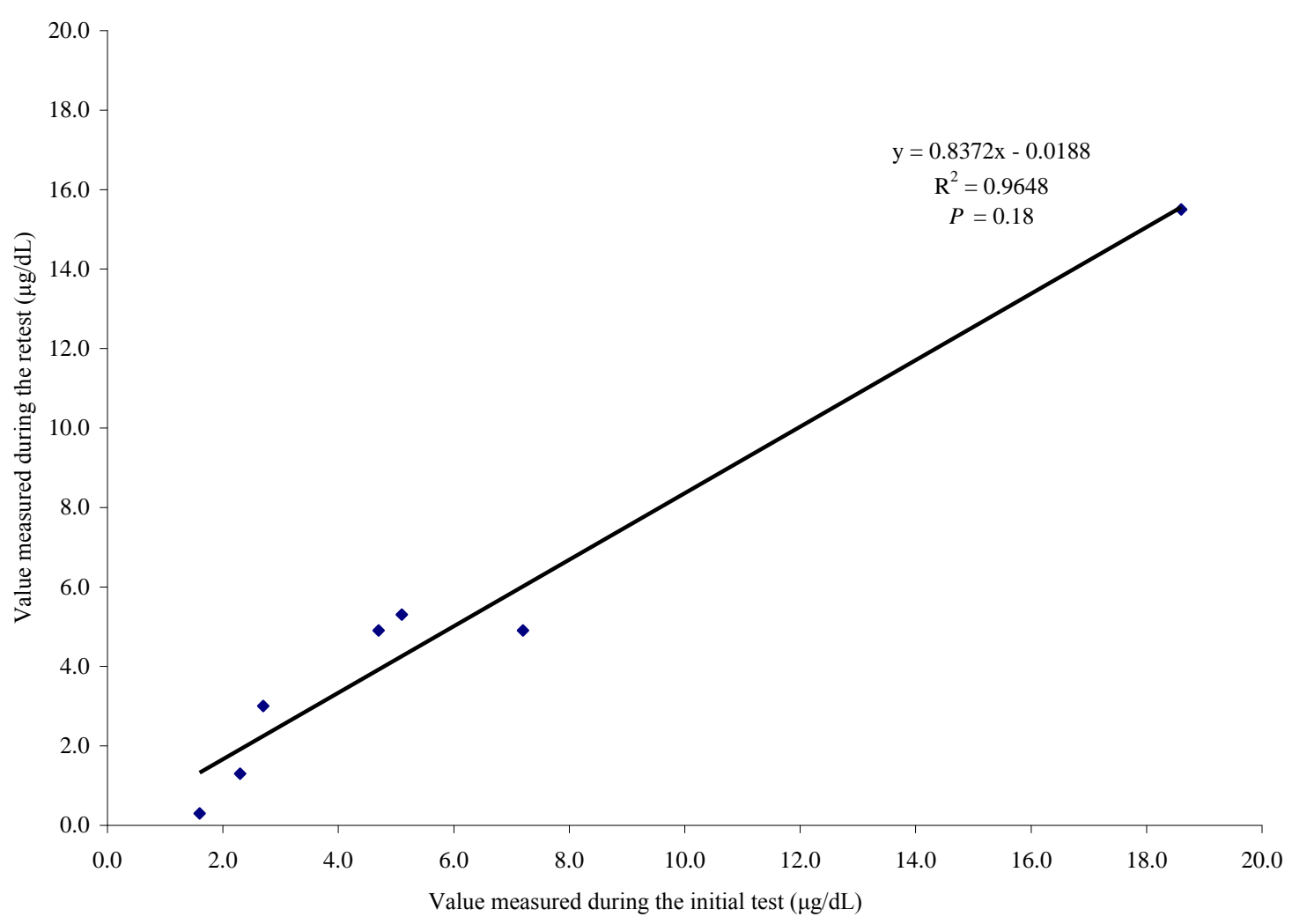

Figure 9. Difference between the value measured during the initial test and the value measured one year later during using LCS. The values measured one year later were lower than the original test $(-1.0 \mu \mathrm{g} / \mathrm{dL})$, but this difference was not significant $(P=0.18)$, and these values were also within normal range of variation defined by ESA for the control blood samples.

In addition, with the exception of the one extreme outlier, all of the samples were within the values expected when running the control samples of bovine blood with 
known amounts of lead provided by ESA, Inc. for the use in testing the validity of the LCS. While the control BLLs vary slightly from batch to batch, they are generally very close to $7 \mu \mathrm{g} / \mathrm{dL}$ for the "low" BLL control and $27 \mu \mathrm{g} / \mathrm{dL}$ for the "high" BLL control sample, and the expected variation is $\pm 3 \mu \mathrm{g} / \mathrm{dL}$ and $\pm 4 \mu \mathrm{g} / \mathrm{dL}$ for "low" and "high" respectively. The non-outlying retest samples were within this range of variation. 